\title{
Article
}

\section{Developments in nanoparticles for use in biosensors to assess food safety and quality}

Warriner, K., Reddy, Subrayal M, Namvar, A. and Neethirajan, S. Available at http://clok.uclan.ac.uk/14371/

Warriner, K., Reddy, Subrayal M ORCID: 0000-0002-7362-184X, Namvar, A. and Neethirajan, S. (2014) Developments in nanoparticles for use in biosensors to assess food safety and quality. Trends in Food Science and Technology, 40 (2). pp. 183-199.

It is advisable to refer to the publisher's version if you intend to cite from the work. http://dx.doi.org/10.1016/j.tifs.2014.07.008

For more information about UCLan's research in this area go to http://www.uclan.ac.uk/researchgroups/ and search for < name of research Group>.

For information about Research generally at UCLan please go to http://www.uclan.ac.uk/research/

All outputs in CLoK are protected by Intellectual Property Rights law, including Copyright law. Copyright, IPR and Moral Rights for the works on this site are retained by the individual authors and/or other copyright owners. Terms and conditions for use of this material are defined in the policies page.

\section{CLoK}

Central Lancashire online Knowledge www.clok.uclan.ac.uk

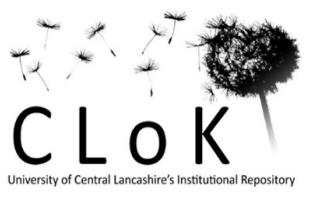


Developments in nanoparticles for use in biosensors to assess food safety and quality

Keith Warriner ${ }^{\mathrm{a}}{ }^{\mathrm{a}}$, , Subrayal M. Reddy ${ }^{\underline{\underline{b}}}$, Azadeh Namvar ${ }^{\mathrm{a}}{ }^{\prime}$, Suresh Neethirajan ${ }^{\mathrm{c},}$

a

Department of Food Science, University of Guelph,

Guelph, Ontario N1G 2W1, Canada (Tel./fax: D1 519

8244120x56072; e-mails: kwarrine@uoguelph.ca, anamvar@uoguelph.ca)

b

Department of Chemistry, FEPS, University of Surrey,

Guildford, Surrey GU2 7XH, UK (e-mail: s.reddy@surrey.ac.uk)

c

School of Engineering, University of Guelph, Guelph,

Ontario N1G 2W1, Canada (e-mail: sneethir@uoguelph.ca)

doi:10.1016/j.tifs.2014.07.008

Highlights

-Background to the evolution of biosensor based on nanoparticles.

-Application of nanoparticles in biosensor devices.

- Overview of biosensor formats applied in food testing.

-Examples of integrated biosensor systems for food sampling.

-Prospects and challenges in nanosensors in pathogen testing.

The following will provide an overview on how advances in nanoparticle technology have contributed towards developing biosensors to screen for safety and quality markers associated with foods. The novel properties of nanoparticles will be described and how such characteristics have been exploited in sensor design will be provided. All the biosensor formats were initially developed for the health care sector to meet the demand for point-of-care diagnostics. As a consequence, research has been directed towards miniaturization thereby reducing the sample volume to nanolitres. However, the needs of the food sector are very different which may ultimately limit commercial application of nanoparticle based nanosensors.

Introduction

Through evolution we have developed senses to enable us to differentiate good foods from bad. The art of cheese making, brewing and viticulture has relied on the producer using their senses to assess quality. Establishing if a food was safe was more problematic and typically relied on tasters to ensure 
dishes provided to their masters were sound. Clearly, analytical testing is a more reliable and objective means of assessing the quality and safety of foods. Laboratory testing provided a basis for developing protocols and limits that could be applied to foods to define quality or safety. Yet, the expense and delay in acquiring results remain critical limitations. Consequently, there is an on-going demand for biosensors that can be used outside the laboratory environment to assess the safety and quality of foods on-site.

In many instances the needs of the food industry mirrored that of the health sector where rapid diagnostics would enhance treatments and prognosis. The health sector provides a more lucrative market for diagnostic companies so it is not unexpected to find that the majority of research to date has been towards developing biosensors to meet the market demands. Consequently, those biosensors encountered in the food sector are derived from those devices initially fabricated to meet the needs of the health care sector. Within this context, the following review provides a brief history on how the field of biosensors developed and the contribution made by advances in nanoparticle technology. The efforts in transferring biosensor technologies to the food sector will be provided with a focus on safety, and to a degree, quality assessment. The review does not attempt to provide an exhaustive list of advances given the numerous quality reviews are already published in this area (Arugula and Simonian, 2014, Bonanni and del Valle, 2010, Das et al., 2014, Ding and Heiden, 2014, Lee et al., 2013 and Lim and Kim, 2014). Instead, the current review will provide trends in biosensing strategies based on nanoparticles and what potential barriers exist with respect to commercialization of such devices within the food sector.

\section{A brief history of biosensors}

The first biosensor was reported by Clarke \& Lyons in 1962 and consisted of an oxygen electrode modified with glucose oxidase and an overlaying Teflon ${ }^{\mathrm{TM}}$ membrane. The unit was bulky with the electrode being about the size of a $\mathrm{pH}$ probe and linked to a potentiostat connected to an old pen recorder (R. Singh et al., 2014). The Clarke electrode was further refined to produce the Yellow Spring $24 \mathrm{M}$ glucose analyzer that was commercialized in 1974. The unit was more compact although still a bench-top sized device. The major advance came in the late 1980's when MediSense commercialized the first glucose test strip that consisted of a screen printed electrode with an enzyme layer and mediator immobilized on the anode. Revolutionary at the time, the MediSense sensor was the size of a credit card and required minimal user input with simple graphics to illustrate the blood glucose status of the user. Even through the sensors were not precise ( $>15 \%$ standard deviation) the devices gave a means for those inflicted with diabetes to self-monitor and regulating their condition. So was born the concept of point-of-care sensing which has been, and still is, one of the guiding principles of biosensor research. With advances, glucose sensors have become miniaturized requiring only small sample volumes for testing ( $\mathrm{nl}$ range) with the prospect of implantable devices (Lim and Kim, 2014 and Scognamiglio, 2013). Such advances were based on the discovery of the novel characteristics of nanoparticles that have facilitated target capture along with sensitive signal transduction in biosensor devices.

\section{Biosensors for food analysis}

The diagnostic market is focused on the health care sector for diagnosis and monitoring of medical conditions. Therefore, many of the advances in biosensor research has been directed towards meeting the need of the health sector such as miniaturization to reduce sample volumes and integration to minimize the numbers of steps (such as sample pre-treatment) required for analysis (Ahmed, Saaem, Wu, \& Brown, 2014). Through time there has been interest in applying biosensors in other sectors including food. However, few biosensors have been commercialized for food testing 
due to the varying needs of sensor devices. Specifically, the sample sizes are larger than in medical applications, different sample matrices are encountered and the motivation for actually performing testing. With regards to the latter, the testing performed within the food sector can be subdivided into safety, shelf-life prediction, adulteration and process monitoring (Table 1). The different types of testing have different goals and hence requirements. For fermentation or shelf-life testing the analyte of interest will be present at high levels and hence comparable to medical diagnostics. However, for safety testing there is a need to demonstrate that if a hazard is present then it is at a sufficiently low concentration to pose a negligible risk to human health. For human pathogens such as Salmonella, Escherichia coli 0157:H7 and Listeria monocytogenes there is a need to demonstrate absence in 25-325 g of sample ( Table 1). In the case of mycotoxins the permitted levels are in the order of parts per billion. Ideally, biosensors need to be quantitative although in terms of food safety testing a qualitative analysis suffices provided the lower detection level is within regulatory limits. As one can deduce, the drive to miniaturize biosensors is counter high sensitivity required to screen for pathogens in large sample volumes. For detection of microbial pathogens an enrichment step is applied to enable the target to grow and hence increase in numbers to a point where the sample can be presented to the biosensor device. However, not all pathogens can be cultured (for example, enteric viruses and protozoan) and a culture step adds to the total time for analysis, in addition to requiring containment facilities. Therefore, there is strong interest in culture free techniques that concentrates the target from samples through filtration or selective extraction ( $\mathrm{Namvar}$, Haq, Shields, Amoako, \& Warriner, 2013). Nanotechnology has contributed to this area and as will be described in subsequent sections, the integration of sample preparation and diagnostic platforms is a current trend in biosensor development.

Table 1.

Example of analytes of significance in testing food safety and quality along with regulatory limits.

\begin{tabular}{|c|c|c|c|c|}
\hline Purpose & Class & Example & $\begin{array}{l}\text { Example food } \\
\text { matrix/Regulator } \\
\text { y or guideline } \\
\text { limit }\end{array}$ & Reference \\
\hline \multirow[t]{3}{*}{ Food safety } & Bacteria & $\begin{array}{l}\text { Clostridium } \\
\text { botulinum }\end{array}$ & $\begin{array}{l}\text { Low acid vacuum } \\
\text { packed } \\
\text { foods/Negative } \\
\text { for growth within } \\
\text { shelf-life of the } \\
\text { product }\end{array}$ & Augustin, 2011 \\
\hline & & $\begin{array}{l}\text { Escherichia } \\
\text { coliO157:H7 }\end{array}$ & $\begin{array}{l}\text { Beef } \\
\text { trim/Negative in } \\
375 \mathrm{~g} \text { sample }\end{array}$ & $\begin{array}{l}\text { Bosilevac, } \\
\text { Guerini, Brichta- } \\
\text { Harhay, Arthur, } \\
\text { \& Koohmaraie, } \\
\underline{2007}\end{array}$ \\
\hline & & $\begin{array}{l}\text { Listeria } \\
\text { monocytogenes }\end{array}$ & $\begin{array}{l}\text { Deli } \\
\text { meat/Negative in } \\
25 \mathrm{~g} \text { sample }\end{array}$ & $\frac{\text { Crowley et al., }}{\underline{2014}}$ \\
\hline
\end{tabular}




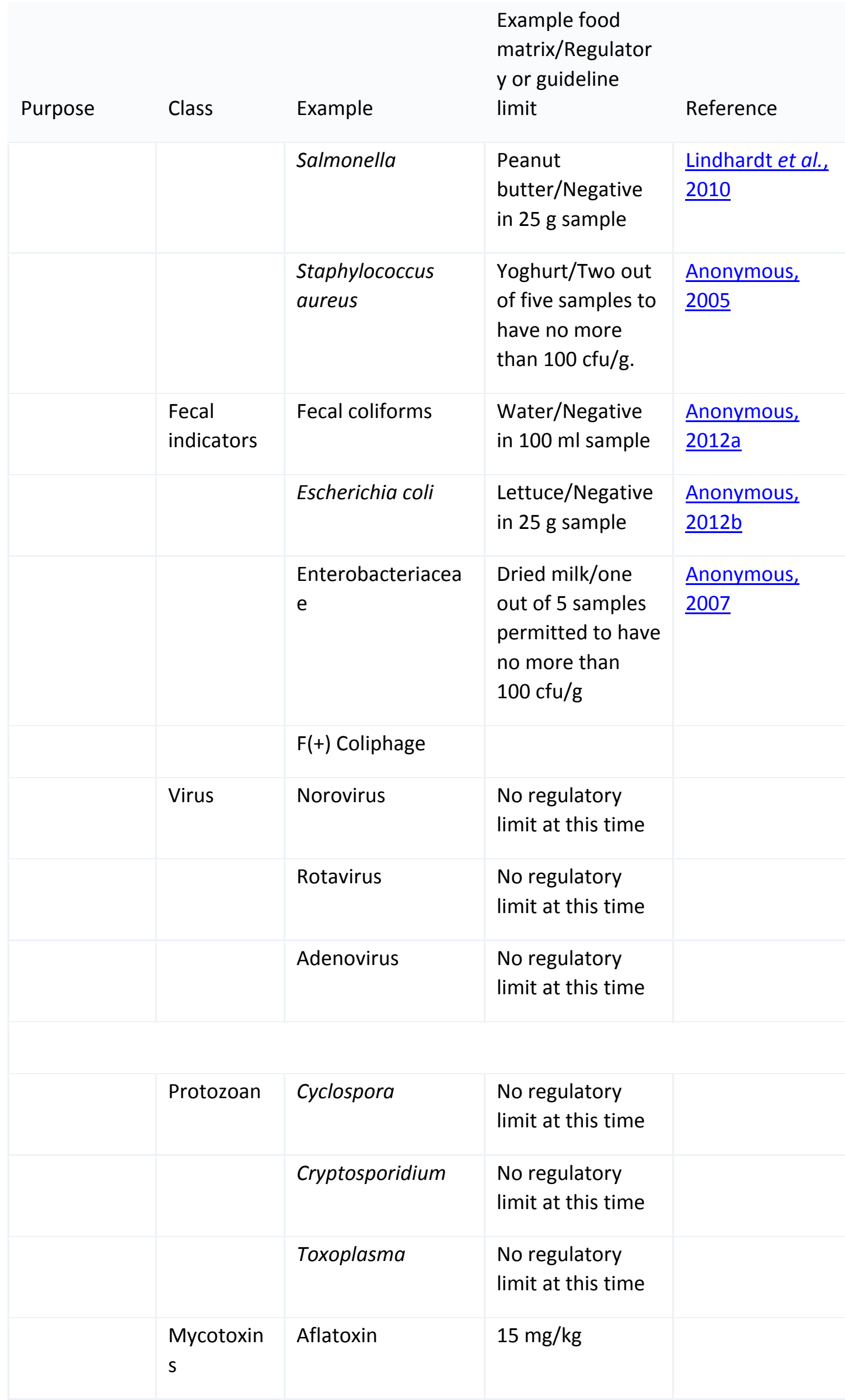




\begin{tabular}{|c|c|c|c|c|}
\hline Purpose & Class & Example & $\begin{array}{l}\text { Example food } \\
\text { matrix/Regulator } \\
\text { y or guideline } \\
\text { limit }\end{array}$ & Reference \\
\hline & & Deoxynivalenol & $2 \mathrm{mg} / \mathrm{kg}$ & \multirow{5}{*}{$\frac{\text { Berthiller et al., }}{2014 \text { and Tothill }}$} \\
\hline & & Fumonisin & $2 \mathrm{mg} / \mathrm{kg}$ & \\
\hline & & Orchratoxin & $0.2 \mathrm{mg} / \mathrm{kg}$ & \\
\hline & & Patulin & $0.5 \mathrm{mg} / \mathrm{kg}$ & \\
\hline & & HT-2 toxin & 0.025 mg/kg & \\
\hline & Allergens & Peanut & $15 \mathrm{mg} / \mathrm{kg}$ & \multirow{5}{*}{$\begin{array}{l}\text { Faeste, Ronning } \\
\text { Christians, \& } \\
\text { Granum, 2011 }\end{array}$} \\
\hline & & Egg & 15 mg/kg & \\
\hline & & Soy & 15 mg/kg & \\
\hline & & Gluten & 20 mg/kg & \\
\hline & & Sulphites & 10 mg/kg & \\
\hline & Pesticides & Methyl bromide & Spices 400 mg/kg & $\begin{array}{l}\text { Desmarchelier } \\
\text { \& Ren, } 1999\end{array}$ \\
\hline & & Picoxystrobin & Barley $0.2 \mathrm{mg} / \mathrm{kg}$ & $\begin{array}{l}\frac{\text { Mikulikova, }}{\text { Svoboda, \& }} \\
\text { Belakova, 2008 }\end{array}$ \\
\hline & & Pinoxaden & Grain $0.01 \mathrm{mg} / \mathrm{kg}$ & \multirow[t]{6}{*}{$\begin{array}{l}\text { Anonymous, } \\
\underline{2013}\end{array}$} \\
\hline \multirow[t]{3}{*}{ Shelf-life } & & TMAO & Not Applicable & \\
\hline & & Oxygen & Not Applicable & \\
\hline & & Xanthine & Not Applicable & \\
\hline \multirow[t]{2}{*}{$\begin{array}{l}\text { Fermentatio } \\
n\end{array}$} & & Glucose & Not Applicable & \\
\hline & & Ethanol & Not Applicable & \\
\hline
\end{tabular}

Note: Regulatory limits may differ between geographical jurisdictions.

$\underline{\text { Table options }}$

Anatomy of a biosensor

At its most basic, a biosensor can be described as having a sensing element for selective detection of target and a method to transduce the interaction as a measureable signal (Thakur \& Ragavan, 2013). 
The original definition of a biosensor was that the recognition element was a biological entity such as an antibody, enzyme, oligonucleotide or receptor. Enzymes are the preferred biorecognition element given the selectivity and ability to amplify the interaction through generation of an electroactive product such as hydrogen peroxide or chromogenic substrate. The detection of target to antibodies, receptors or hybridization of nucleic acid is more problematic given no electroactive or chromagen is formed. Yet, such interactions can be detected using methods such as quartz crystal microbalance (QCM) or Surface Plasmon Resonance (SPR). Previously, radio-labels were used to detect the interaction although these were superseded by enzyme and fluorescent markers with a new generation of labels becoming available through nanoparticles. With respect to the latter, nanotechnology has provided alternatives to biological recognition agents such as molecular imprinted polymers or other artificial receptors (Reddy et al., 2013 and Reddy et al., 2012). There is also interest in direct catalytic nanoparticles that selectively interact with the target thereby negating the need for a biological component. In this respect the definition of biosensors has broadened over the years to include sensors that detect biological systems than limited to those containing a biological component.

The metrics applied to biosensors are devices that can rapidly and selectively detect the target(s) of interest with minimal user input. The novel properties of nanoparticles have found utility in the capture and concentration of analytical targets, in addition to transduction of the bioanalytical interaction. Common nanoparticles applied in biosensor design are depicted in Fig. 1 and described in Table 2. Working at the nanoscale results in unique physical, optical, electrical, magnetic and catalytic properties that differ from the bulk material. Moreover, the properties of nanoparticles are tunable given the chemical and physicochemical characteristics are highly related to size on the nanoscale (Majdalawieh, Kanan, El-Kadri, \& Kanan, 2014). Physically, nanoparticles have a greater surface to volume ratio thereby leading to an overall large working area to undertake chemistries, electrochemistry or immobilization of bioaffinity agents. By working at the nanoscale the optical properties are significantly different compared to bulk materials. For example, gold nanoparticles appear red or black which is very different from the bulk material due to the influence of quantum effects (quantum confinement) which also effects electrical properties. Specifically, the electrons in nanoparticles are densely packed with the energy difference between highest valence band and the low conduction band increases. As a consequence the energy to excite the particle increases with higher energy being released when the electrons return to the ground state. This effect is visualized via a color shift in terms of optical characteristics and semi-conductor properties in terms of electrochemical phenomena such as surface plasmon resonance. A further property of some nanoparticles (e.g. metal oxides) is paramagnetism resulting from a lower number of unpaired electrons compared to the bulk material. The net result is a lower level of magnetism compared to the bulk material but exhibits ferromagnetism under the influence of a magnetic field. As will be elaborated upon in subsequent sections, the properties of nanoparticles, especially composites, have found utility in biosensor design. 


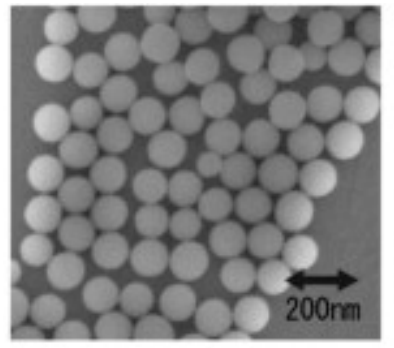

Fluorescent Silica

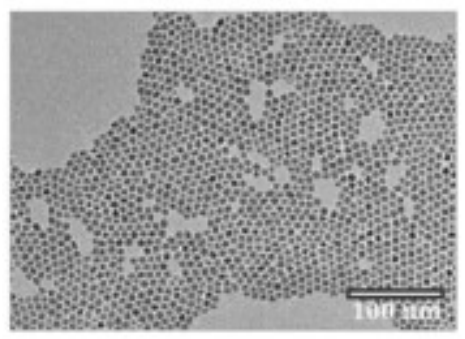

Quantum Dots

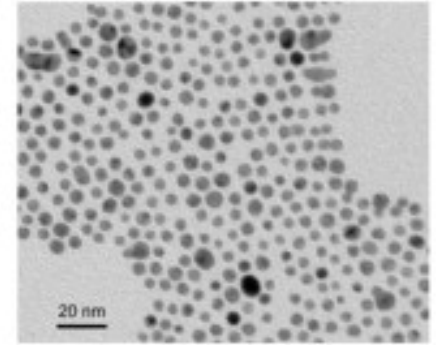

Gold Nanobeads

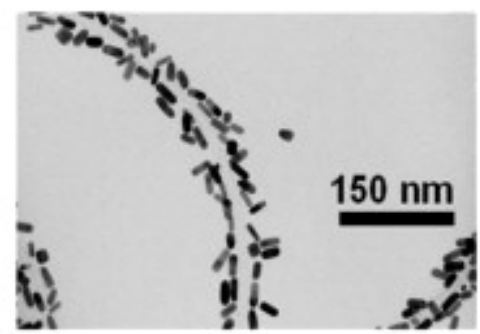

Carbon Nanotubes

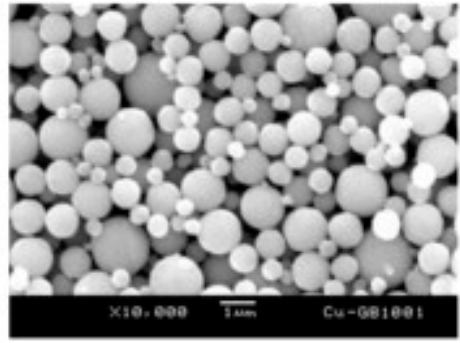

Zinc Oxide Nanobeads

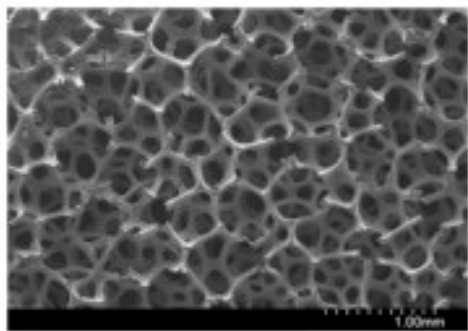

Graphene

Fig. 1.

Transmission electron microscopy monographs of nanoparticles commonly applied in biosensor fabrication.

\section{Figure options}

Table 2.

Properties and functionality of nanoparticles commonly used in biosensor fabrication.

\begin{tabular}{|c|c|c|c|c|}
\hline $\begin{array}{l}\text { Class of } \\
\text { nanoparticle }\end{array}$ & Material & Properties & Application & Reference \\
\hline \multirow[t]{7}{*}{$\begin{array}{l}\text { Transition } \\
\text { metals }\end{array}$} & Gold & Immobilization & $\begin{array}{l}\text { Biorecognition } \\
\text { agent } \\
\text { immobilization }\end{array}$ & $\begin{array}{l}\text { J. Cao, Sun, \& } \\
\text { Grattan, } 2014\end{array}$ \\
\hline & & Label & Fluorescent label & \\
\hline & & Catalyst & Catalysts & \\
\hline & Silver & Immobilization & $\begin{array}{l}\text { Biorecognition } \\
\text { agent } \\
\text { immobilization }\end{array}$ & $\begin{array}{l}\text { Chen, Yuan, Chai, } \\
\underline{\text { \& Hu, } 2013}\end{array}$ \\
\hline & & Label & Fluorescent label & \\
\hline & & Catalytic & Catalysts & \\
\hline & $\begin{array}{l}\text { Palladium, } \\
\text { Copper, } \\
\text { Nickel }\end{array}$ & Catalytic & Direct oxidation & Chen et al., 2013 \\
\hline
\end{tabular}




\begin{tabular}{|c|c|c|c|c|}
\hline $\begin{array}{l}\text { Class of } \\
\text { nanoparticle }\end{array}$ & Material & Properties & Application & Reference \\
\hline \multirow[t]{14}{*}{ Metal oxides } & Zinc oxide & Semi-conductor & $\begin{array}{l}\text { Direct enzyme } \\
\text { wiring }\end{array}$ & $\underline{\underline{\text { Gomez \& Tigli, }}}$ \\
\hline & & Mediator & $\begin{array}{l}\text { Biorecognition } \\
\text { agent } \\
\text { immobilization }\end{array}$ & \\
\hline & & $\begin{array}{l}\text { Protein } \\
\text { absorption }\end{array}$ & & \\
\hline & & $\begin{array}{l}\text { Isoelectric point } \\
\mathrm{pH} 9.5\end{array}$ & & \\
\hline & $\begin{array}{l}\text { Titanium } \\
\text { oxide }\end{array}$ & Photocatalytic & Labels & $\begin{array}{l}\text { Li, Cheng, Weng, } \\
\text { Du, \& Han, } 2012\end{array}$ \\
\hline & & $\begin{array}{l}\text { Protein } \\
\text { absorption }\end{array}$ & Catalyst & \\
\hline & Iron oxide & Paramagnetic & $\begin{array}{l}\text { Biorecognition } \\
\text { agent } \\
\text { immobilization }\end{array}$ & \\
\hline & & $\begin{array}{l}\text { Ease of } \\
\text { fabrication }\end{array}$ & $\begin{array}{l}\text { Target } \\
\text { concentration }\end{array}$ & \\
\hline & & Catalyst & $\begin{array}{l}\text { Direct } \\
\text { electrooxidation } \\
\text { of peroxide and } \\
\text { glucose }\end{array}$ & \\
\hline & Zirconia & $\begin{array}{l}\text { Protein } \\
\text { absorption }\end{array}$ & $\begin{array}{l}\text { Bioaffinity agent } \\
\text { immobilization }\end{array}$ & $\begin{array}{l}\text { Liu, Cao, Chen, } \\
\text { Kong, \& Deng, } \\
\underline{\underline{2003}}\end{array}$ \\
\hline & Nickel oxide & $\begin{array}{l}\text { Protein } \\
\text { absorption }\end{array}$ & $\begin{array}{l}\text { Bioaffinity agent } \\
\text { immobilization }\end{array}$ & $\begin{array}{l}\text { Moghaddam, } \\
\text { Ganjali, \& } \\
\text { Saboury, 2008 }\end{array}$ \\
\hline & & Semi-conductor & $\begin{array}{l}\text { Direct enzyme } \\
\text { wiring }\end{array}$ & \\
\hline & $\begin{array}{l}\text { Manganese } \\
\text { oxide }\end{array}$ & $\begin{array}{l}\text { Protein } \\
\text { absorption }\end{array}$ & $\begin{array}{l}\text { Bioaffinity agent } \\
\text { immobilization }\end{array}$ & $\begin{array}{l}\text { Luo, Xu, Zhao, \& } \\
\text { Chen, } 2004\end{array}$ \\
\hline & & Catalyst & $\begin{array}{l}\text { Direct oxidation of } \\
\text { glucose }\end{array}$ & \\
\hline
\end{tabular}




\begin{tabular}{|c|c|c|c|c|}
\hline $\begin{array}{l}\text { Class of } \\
\text { nanoparticle }\end{array}$ & Material & Properties & Application & Reference \\
\hline \multirow[t]{5}{*}{ Fluorescent } & $\begin{array}{l}\text { Fluorescent } \\
\text { silica }\end{array}$ & High intensity & Labeling & $\begin{array}{l}\text { Nagy, Gemmill, } \\
\text { Delehanty, } \\
\text { Medintz, \& } \\
\text { Sapsford, 2014 }\end{array}$ \\
\hline & & $\begin{array}{l}\text { Encapsulating } \\
\text { fluorescent dyes }\end{array}$ & Biocompatibility & \\
\hline & $\begin{array}{l}\text { Quantum } \\
\text { dots }\end{array}$ & Semi-conductor & Labeling & Nagy et al., 2014 \\
\hline & & $\begin{array}{l}\text { Narrow } \\
\text { emission } \\
\text { spectra }\end{array}$ & $\begin{array}{l}\text { Electrochemical } \\
\text { detection }\end{array}$ & \\
\hline & & Stable & & \\
\hline \multirow[t]{9}{*}{ Carbon } & Nanotubes & $\begin{array}{l}\text { Thermal } \\
\text { conductivity }\end{array}$ & Electrode & Li \& Shi, 2014 \\
\hline & & $\begin{array}{l}\text { Electrical } \\
\text { conductivity }\end{array}$ & 3D architecture & \\
\hline & & $\begin{array}{l}\text { Mechanical } \\
\text { strength }\end{array}$ & $\begin{array}{l}\text { Immobilization } \\
\text { matrix }\end{array}$ & \\
\hline & & Catalyst & $\begin{array}{l}\text { Field-effect- } \\
\text { transistors }\end{array}$ & \\
\hline & Graphene & $\begin{array}{l}\text { Bioaffinity } \\
\text { molecule } \\
\text { immobilization }\end{array}$ & $\begin{array}{l}\text { Enzyme } \\
\text { immobilization }\end{array}$ & $\underline{\underline{2014}}$ \\
\hline & & Semi-conductor & & \\
\hline & Nanowires & Semi-conductor & $\begin{array}{l}\text { Label-free } \\
\text { detection }\end{array}$ & $\underline{\underline{2014}}$ \\
\hline & & $\begin{array}{l}\text { Large surface } \\
\text { area }\end{array}$ & $\begin{array}{l}\text { Field-effect- } \\
\text { transistors }\end{array}$ & \\
\hline & & $\begin{array}{l}\text { Mechanical } \\
\text { strength }\end{array}$ & & \\
\hline
\end{tabular}

\section{Table options}

It is fair to state that nanoparticles alone have not been solely being responsible for advances in diagnostics although have contributed along with other innovations in engineering, polymer chemistry, biochemistry, physics and molecular biology. Therefore, to appreciate the role of 
nanoparticles it is informative to briefly review advances made in signal transduction techniques along with biorecognition elements.

Transduction techniques and microfluidics

In broad terms the transduction techniques used in biosensors can be described as electrochemical or optical based. The main advantage with electrochemical transduction is the simplified design, sensitivity and amenable to miniaturization (Arugula \& Simonian, 2014). Optical transduction is regarded as sensitive equal to or greater than electrochemical although has the disadvantage of needing camera/detectors for quantitative measurements (Thakur \& Ragavan, 2013). Yet, because most sensors are qualitative many rely on visual inspection to assess a positive or negative tests result.

The original concept of the biosensor were those devices that could be used outside the laboratory environment. Current commercial biosensors for out-of-lab testing were until relatively recently limited to optical fibers, dip sticks, lateral flow immunoassay and amperometric devices. Yet, research has used a more diverse array of sophisticated interrogation techniques to monitor the interaction of target with bioaffinity agents. Although primarily laboratory based, the advances in nanotechnology have enabled portable devices to become a reality. Such advances have provided a diverse range of diagnostic platforms that have enabled the unique properties of nanoparticles to be exploited. It is out of the scope of this review to go into great details on the advances made in instrumentation but it is informative to provide an overview of the different sensing principles of the technology available for biosensor design.

Electrochemical sensors

Amperometry measures the current generated/consumed from oxidation/reduction reactions at the working electrode surface. The arrangement can be composed of a two electrode arrangement whereby the counter electrode also functions as the reference. Three electrode systems have a separate reference electrode that enables the applied potential to be controlled. Potential dynamic techniques such as cyclic voltammetry, differential pulse voltammetry, square wave voltammetry, amongst others, provide an extra level of selectivity by separating electroactive species based on redox potential. A further advantage of dynamic potential techniques is cleaning of the electrode surface to minimize biofouling by sample constituents or byproducts of the electrochemical reaction.

Potentiometric sensors are based on measuring the change in potential between the working and reference electrode which in turn depends on the mobility, in addition to the activity of ions. Ion selective electrodes and gas sensors are primary potentiometric sensors although a diverse range of other types have been fabricated (Sliwinska, Wisniewska, Dymerski, Namiesnik, \& Wardencki, 2014).

Conductometric sensors are based on the changes in electrical resistance between two electrodes. A selection of the nanoparticles encountered in biosensor devices are semi-conductors that modify conductivity in response to changes in the electrode surface (for example, binding of target to bioaffinity agent). Sensors based on conductance can use a simple voltage meter although AC impedance can be applied to enhance sensitivity and also selectivity.

Piezoelectric sensors

Quartz crystal microbalance (QCM) is a bulk acoustic wave (BAW) sensor that measures the change in frequency of a quartz crystal resonator induced by mass and viscoelastic changes at the QCM surface (e.g. the binding of target to an immobilized bioaffinity agent). The resonance of the quartz crystal is monitored using AC impedance which measures the shift in frequency and can be related 
to the mass change. The QCM is highly sensitive and can measure mass changes in the order of $1 \mathrm{\mu g} / \mathrm{cm}^{2}$ although can be prone to interference from non-specific binding effects. Surface acoustic wave (SAW) sensing is a related technique to QCM and is classed in the broader group of acoustic wave devices. SAW sensors changes in the modulation of surface (as opposed to the bulk) acoustic waves induced by a change in surface effects such as mass but also includes viscosity, UV irradiation, magnetic fields, pressure, strain and temperature (Arugula \& Simonian, 2014).

Optical sensors

Surface plasmon resonance is frequently referred to as a mass sensor it can also be an optical based technique. The principle of the SPR is based on the generation of a plasmon waves on a dielectric interface and measurement of the angle of reflectance. When the refractive index of the surface changes (for example, binding of target to bioaffinity agent) so too is the reflectance angle. The first SPR units built in the 1980's were very large but by the mid-1990s had been scaled down to bench size devices. Today portable SPR units are available and used extensively to monitor molecular interactions in real time (Bonanni \& del Valle, 2010).

\section{Magnetoresistance sensors}

Magnetoresistive sensors measure the changes in metal resistivity under the influence of a magnetic field. Although research in magnetoresistance biosensors is at an early stage it can be envisaged that the technique will prove a powerful technique in the field of nanosensors. In one format, magnetoresistance sensors exploit the changes in magnetism of paramagnetic beads that provides a more selective and sensitive (lower detection limit of $10 \mathrm{pg} / \mathrm{l}$ ) label compared to traditional fluorescent labels (Zhi et al., 2014).

Microfluidic (lab-on-a-chip) sensors

In addition to miniaturization of transduction techniques (Top-Down Approach to sensor design) there have also been advances in developing lab-on-chip devices. The advent of affordable microfluidic devices has been central in developing nanosensors (Kumaret al., 2013). Microfluidics enables small ( $\mathrm{nl}$ ) sample volumes to be precisely manipulated in terms of flow, mixing, heating and cooling. In addition, microfluidics have facilitated the ability to fully integrate extraction and detection on a single chip, hence the term Lab-on-a-Chip. By working with small volumes, less reagents are required with the added advantages of high sensitivity along with rapid assay times within an automated system. Immunosensor and hybridization assays have been adapted to microfluidic systems with label free devices being described (Nahavandi et al., 2014). Enzyme microfluidic assays for detection of a range of substrates (sugar, lipids, acids) have also been fabricated (Nahavandi et al., 2014). One of the more interesting innovations is the ability to perform polymerase chain (PCR) reaction within a microfluidic system (Shu, Zhang, \& Xing, 2014). PCR is routinely used for pathogen detection due to sensitivity and selectivity compared to culture based methods. Although Real Time-PCR enables rapid detection of pathogens the units are bench scale and therefore incompatible with biosensors. Yet, a continuous flow PCR microfluidic chip coupled with hybridization enable detection of multiple pathogens in an automated device (Jiang et al., 2014). With advances in isothermal PCR techniques that does not require thermal cycling it can be envisaged that major advances in pathogen detection and is currently under development (Zhi et al., 2014).

Nanoparticles application in biosensor design

Immobilization of bioaffinity agents 
The first biosensors immobilized enzymes or antibodies via cross-linking agents such as glutaraldehyde with bovine serum albumin acting as cross-linking/blocking agent. The immobilization was random and resulted in a proportion of the enzyme being denatured. Nanoparticles have overcome such limitations by enabling high loading efficacy with controlled orientation and in many instances, dual functionality such as magnetic separation (concentration) or signal transduction.

Immobilization of bioaffinity agents can be via non-covalent bonding onto charged surfaces thereby negating the need for chemical coupling and retaining high activity of the enzyme or antibody. For non-covalent binding the nanobeads of interest are zirconia that are essentially inert but readily absorbs proteins. Functionalized silica beads also provide a charged surface by which proteins can be absorbed via ionic bounds. Iron or zinc oxide beads can also be used to absorb protein bioaffinity agents by virtue of carrying a net negative charge at neutral pH (Gomez \& Tigli, 2013). However, as with all non-covalent bonding, the attachment of proteins is sensitive to $\mathrm{pH}$, ionic strength and/or temperature. Therefore, covalent linkage is preferred for immobilization of bioaffinity agents onto the surfaces of the nanoparticles. The most common example of covalent bonding is with gold nanoparticles which are amenable to coupling via thiol bonds. The relatively simple chemistry of gold surfaces makes it suitable to immobilize a diverse range of bioaffinity agents such as antibodies, oligonucleotides and enzymes. With respect to the latter, the high electrical conductivity of gold nanoparticles enhances electron transfer and hence the sensitivity of the assay (Majdalawieh et al., 2014). Gold nanoparticles also exhibit novel optical properties which alter with interaction of target (antigen or oligonucleotide) with immobilized bioaffinity agent.

Covalent bonding of bioaffinity agents can also take place of metal oxide nanobeads although require to be functionalized with organic (e.g. lauric acid) or inorganic (silicon oxide) derivatives (Frenzel, Lajn, \& Grundmann, 2013). For proteins the covalent bonding is achieved through glutaraldehyde or 1-ethyl-3-(3-dimethylaminopropyl) carbodiimide hydrochloride (EDC) coupling agent (Mishra, Srivastava, Kumar, Biradar, \& Rajesh, 2013). For covalent bonding the outer shell of metal oxide beads are modified with silica to impart functional groups to covalently link the bioaffinity agent. Previous interest in immobilizing bioaffinity agents (antibodies or bacteriophages) on paramagnetic beads was as a concentration step referred to as immuno-magnetic separation (IMS) that used beads in the micron size range. However, IMS based on nanobeads have the advantage of higher antibody loading by virtue of increased surface area although stronger magnetic fields are required to facilitate bead capture (Shenet al., 2014). Hitherto, IMS has been used to negate, or reduce the time required for the enrichment step for pathogen screening. Here, the sample (homogenized food or enrichment broth) is mixed with or flowed over, modifiedparamagnetic beads that captures the target which can then be transferred to a diagnostic platform such as real time-PCR (Fedio et al., 2011). Recent advances in the application of paramagnetic beads is the integration of capture, concentration and detection in a single integrated unit. For example, ELISA based assay where the target is captured and reacts with a conjugate has been described for detection of h3/4 peanut allergen with a $0.2 \mathrm{mg} / \mathrm{kg}$ limit of detection (Speroni, Elviri, Careri, \& Mangia, 2010).

Alternative biorecognition elements

\section{Bacteriophages and receptors}

Bacteriophages are viruses that infect bacteria in order to multiply at the cost of the host cell viability (Smartt et al., 2012). In evolutionary terms, bacteriophage has been a central part of evolution through transferring genes between species and even across genera. For biosensor 
purposes, bacteriophages have found utility as biorecognition agents for bacteria given the high degree of specificity and stability relative to antibodies (A. Singh, Poshtiban, \& Evoy, 2013). Bacteriophages have also been used as biorecognition elements for a broader spectrum of targets through advances in phage display (Leeet al., 2013). Here, through modification of the genetic code of bacteriophages it is possible to modify the protein composition of the capsid when expressed in the bacterial host. The introduced genes can encode to proteins with affinity towards a range of targets similar to that antibodies (Lee et al., 2013). For example, peptides have been expressed on the surface of E2 bacteriophages with affinity towards SalmonellaTyphimurium. When combined with QCM it was possible to detect 2 log cfu/ml within 3 min ( Mi-Kyung, Suiqiong, \& Chin, 2013). In a further example, phages engineered to display affinity proteins against Salmonella and combined with magnetoelastic resonance (MER) (Lakshmanan et al., 2007). ME resonance is based on detecting changes in the dimensions of the target when exposed to short magnetic pulses with the characteristic resonance frequency and amplitude being detected. When phage bind to the Salmonella target a quantitative decrease in resonance is observed enabling real time detection of the pathogen on surfaces. For example, as low as $50 \mathrm{cfu} / \mathrm{ml}$ ofSalmonella can be detected on the surface of tomatoes using the ME resonance and bacteriophage combination ( Lee et al., 2013).

It is also possible to alter the gene sequence of phages to display regions on the subsequent phage coat to facilitate coupling of fluorescent dyes or attachment sites on nanobeads for correct orientation (Smartt et al., 2012). A further interesting application of bacteriophages is to act as inert supports to orientate oligonucleotides probes or generating ultra-thin, highly orientated, nanowires. With the latter, the phage act as an insulating scaffold with functional groups that enable attachment of silica coaxial nanocables (Kim et al., 2013). The use of phages for 3D nanoscale construction is predicted to be the basis of the next generation of sensors although is only an emerging area at this time.

An alternative to antibodies is the modification of paramagnetic beads with molecules with affinity towards to target. For example, many antibiotics inhibit bacteria through binding to peptidoglycan thereby inhibiting growth (Blecher \& Friedman, 2012). This binding property has been exploited with ferric oxide nanobeads modified with the antibiotic vancomycin coupled with MALDI-MS downstream detection. The antibiotic modified beads could bind both Gram positive and negative bacteria down to $2 \mathrm{log} \mathrm{cfu} / \mathrm{ml}$ with an analysis time of $60 \mathrm{~min}$ (Blecher \& Friedman, 2012). Biosensors have also been described whereby the phage have been genetically modified to express a biotinylated peptide that is used to couple quantum dots via a streptavidin bridge. In this instance the quantum dot acts as a fluorescent label enabling simultaneous capture and detection with a reported sensitivity of 10 cells $/ \mathrm{ml}$ (Lee et al., 2013).

\section{Artificial bioaffinity elements}

The biological component of a biosensor is considered the most costly and weakest part of the design. For example, antibodies are produced in tissue culture or animals and are expensive. Moreover, developing selective antibodies can take a year or more due to the multiple steps incurred. As with other biological recognition agents, the fragility also reduces the shelf-life of the sensor and necessitates special storage such as refrigeration. Therefore, there has been strong interest in developing artificial or synthetic affinity agents as a substitute for those of biological origins. The most promising artificial receptors are aptamers and molecular imprinted polymers, both of which have found utility in sensor designs for analytes of interest to the food sector (Ju et al., 2011). Of specific relevance is the relatively new technique of surface imprinting onto paramagnetic nanobeads using Atom Transfer Radical Polymerization (ATRP). Here the surface of ferric oxide nanobeads are functionalized with 2-bromoisobutyryl that acts as an anchor point (initiator) to 
elongating polymer. The template, monomer and cross-linking agent are added along with the initiator (e.g. $\mathrm{CuCl}_{2}$ ). Unlike traditional MIP synthesis, the elongation of the growing polymer proceeds in a controlled and ordered manner. Upon completion of the polymerization process the template is removed leaving voids with the affinity for the target (Salian \& Byrne, 2013). To date model proteins such as lysozyme, BSA and myoglobin have been imprinted but this has now been extended to other biological targets such as Tobacco Mosaic Virus (uㅡ, 2013; Fig. 2). By grafting the imprinted polymer onto the surface of paramagnetic beads it is possible to concentrate the target by applying a magnetic field.

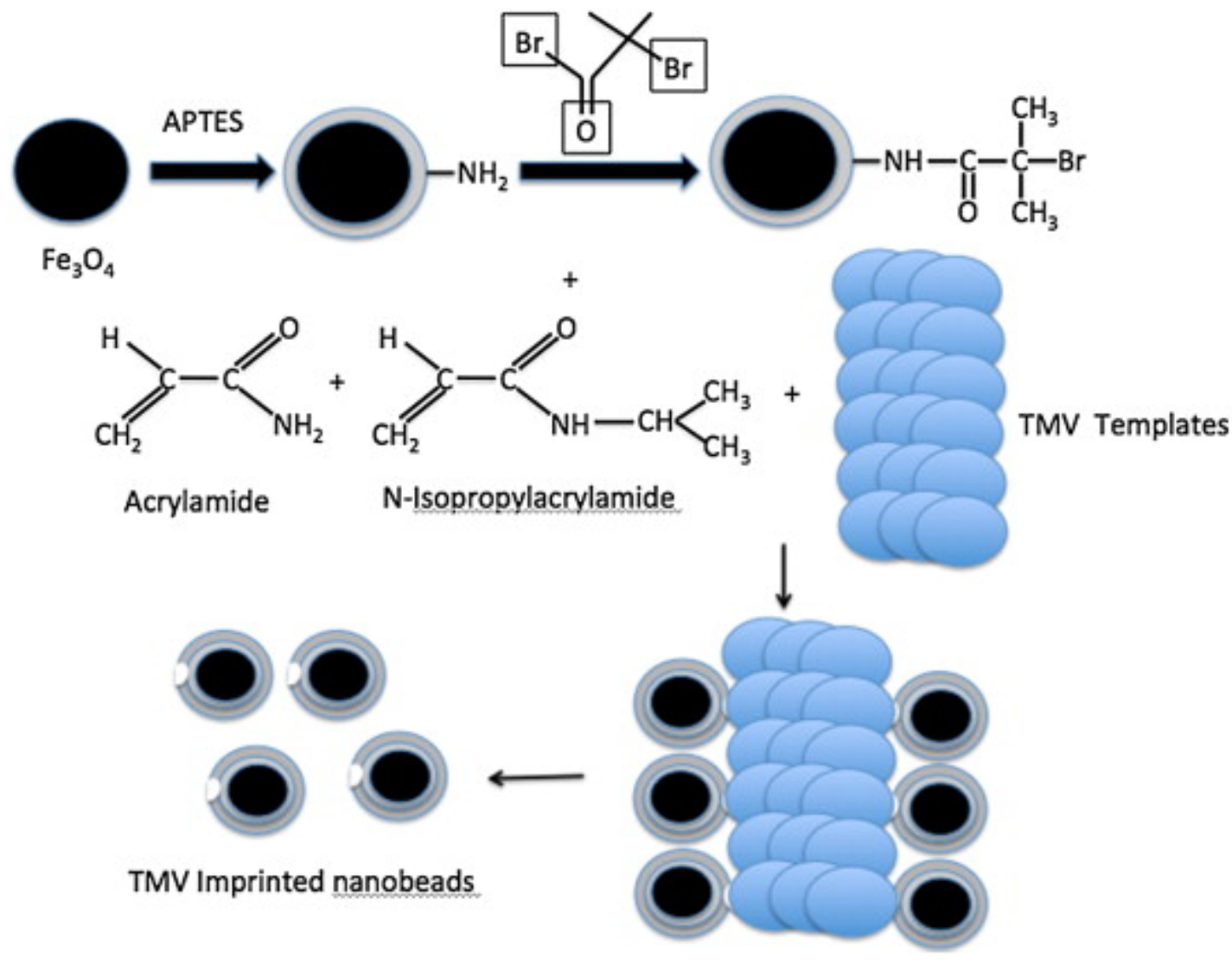

Fig. 2.

Schematic representation of generation of $\mathrm{Fe}_{3} \mathrm{O}_{4}$ nanoparticles modified with ATRP to fabricate Tobacco Mosaic Virus surface-imprinted polymer. Nanobeads (in black) are functionalized with a silica layer (in gray) and the coated silica layer beads grafted carbon-halide bond $(-\mathrm{CBr})$ to form the ATRP initiator. Polymerization of the monomer ( $\mathrm{N}$-isopropylacrylamide) and assistant monomer (acrylamide) along with cross-linker ( $\mathrm{N}, \mathrm{N}$-methylenebisacrylamide) is initiated in presence of TMV template. The template is removed following the imprinting process to yield the TMV-imprinted nanobeads (Sun, 2013).

\section{Figure options}

Enzyme wiring to electrodes

The majority of enzymes used in biosensors are oxidoreductases that produce an electroactive product that can be detected amperometrically. Oxygen can serve as an electron acceptor for oxidase enzymes although high over potentials are required which can lead to interference from other electroactive constituents within the sample (for example, ascorbic acid). Therefore, mediators (e.g. ferrocene) can be used in place of oxygen although this necessitates physical 
addition to the assay or immobilization along with the enzyme. Dehydrogenase enzymes also require mediators to regenerate $\mathrm{NAD}(\mathrm{P})^{+}$which can complicate electrode design (Teymourian, Salimi, \& Hallaj, 2012). As a consequence there has been a sustained research effort to directly wire the redox center of the enzyme to the electrode thereby negating the need for exogenous mediator. Previously it has been claimed that enzymes deposited on electrodes within a conducting polymer matrix could be used to wire electrodes although evidence is far from conclusive (Lima \& Maia, 2014). In terms of nanomaterials, direct electron transfer between microperoxidase or horseradish peroxidase and supporting electrode (Au or graphene oxide) was facilitated by $\mathrm{ZnO}$ paramagnetic beads modified with chitosan (Palanisamy, Cheemalapati, \& Chen, 2012; Hu, Zhang, Zhang, Luo, \& Yao, 2012). Uricase absorbed onto $\mathrm{ZnO}$ nanowires has also been demonstrated to be a means of directly wiring the redox center of the enzyme to electrode surfaces (Y. G. Zhao et al., 2013). In a similar manner, titanium dioxide nanorods have been shown to facilitate direct electron transfer from the active site of glucose oxidase to a supporting glassy carbon electrode (Yang, Tang, Li, Zhang, \& Hu, 2014). Nitrogen doped carbon nanotubes have been used for the same purpose (Antiochia and Gorton, 2014 and Deng et al., 2009).

Although there is mounting evidence for direct wiring of enzymes to electrodes it should be noted that even the small size of nanoparticles could not directly access the redox center of most enzymes. Still, direct wiring negates the need to include mediators and offers the potential of rapid electron transfer, hence rapid response, in addition to increased sensitivity.

Enzyme-free modified electrodes

In addition to other characteristics, nanoparticles exhibit electrocatalytic behavior that can potentially substitute for enzyme-free oxidation of targets of interest. By avoiding the use of enzymes the cost of sensors can be reduced and shelf-life increased. More significantly, by omitting the enzyme it is possible to sterilize the sensor as part of Clean-in-Place procedures common to the fermentation industry (Warriner et al., 2002). Ethanol and glucose have been the main target of interest due to medical significance although is also relevant for monitoring the progress of fermentations.

The direct oxidation of glucose can be achieved using gold electrodes although requires alkaline conditions and high over-potential (Warriner et al., 2002). The oxidation of glucose can also result in significant electrode fouling and hence needs to be used in combination with pulsed amperometric detection. Such limitations can be overcome using nanoparticles. For example, the detection of glucose in a sensor utilizing nickel-sulphide:carbon nanotube composite electrodes was possible without biofouling or interference from uric and ascorbic acid (Lin, Liu, \& Dai, 2014). Oxidation of glucose at Au nanoparticles with an outer coating of poly( $\mathrm{N}$-vinyl-2poyrrolidone) has also been reported (H. J. Zhang, Li, Gu, \& Zhang, 2014).

An ethanol sensor based on nickel nanoparticle loaded carbon paste electrode has been described (Liu, Zhang, Guo, Hou, \& You, 2010). The novel feature of the sensor is the formation of the nickel:carbon electrode by electrospining thereby forming free standing fibers without the need for sophisticated patterning. The amperometric sensors exhibited a lower detection limit of $0.25 \mathrm{mM}$ in wine with negligible interference from background constituents.

\section{Genosensors}

DNA is a unique target used for the detection of pathogens, in addition to those microbes that are difficult or impossible to culture in the laboratory. Beyond pathogen screening there is interest in screening meat products for authenticity and DNA from foods associated as a source of allergens, for 
example peanut (Espineira et al., 2010 and Meyer, 2000). There have been significant advances in DNA based diagnostics to the extent that a whole bacterial genome can be sequenced within a week. To put this into perspective, the human genome project initiated in the 1990's took over 13 years with a cost of $\$ 3 \mathrm{bn}$. If the same project was performed today the process would take two months at a cost of around $\$ 10,000$.

Biosensors based on nucleic acid detection are primarily based on hybridization. Here, the target DNA or RNA is amplified via PCR or extracted from the sample under test. Probes are immobilized on a surface then hybridized with the target if present. One of the major challenges in nucleic acid based sensors is the precise technique to detect the hybridization event to the extent that a single base mismatch can be detected to minimize false positives (Mortari \& Lorenzelli, 2014).

Nanoparticles have been introduced into the development of nucleic acid based sensors although the area is still under development. Oligonucleotide probes have been immobilized onto the surface of paramagnetic beads to enhance the hybridization process and permit concentration of the target under the influence of a magnetic field (Z.Wang et al., 2013). There are electrochemical and optical approaches to differentiate between hybridized and non-hybridized probes. In one example, an $E$. coli 0157:H7 sensor has been described based QCM using nanobeads modified with oligonucleotides ( Paniel, Baudart, Hayat, \& Barthelmebs, 2013). Here, the mass of the nanobeads result in a change in the measured frequency. AC impedance is a related technique to QCM but measures the capacitance and charge transfer resistance at the electrode interface. Genosensors have been described where hybridization between target and probes immobilized onto carbon nanotubes can be monitored through changes in the charge transfer resistance (R. Singh et al., 2014). The sensor format has been used to detect genetically modified (GM) plants and hepatitis virus (Bonanni \& del Valle, 2010). In a similar format, oligonucleotide probes have been immobilized onto gold nanoparticles that were subsequently deposited onto the surface of poly 2,6-pyridinedicarboxylic acid modified glassy carbon electrodes (Cai, Ai, Yin, \& Shi, 2009). The hybridization of target DNA resulted in an increase in charge transfer resistance of the faradic impedance. The sensor format has been used to detect GM plant material with a sensitivity of $2.4 \times 10^{-11} \mathrm{~mol} / \mathrm{L}$ (Bonanni \& del Valle, 2010). There have been a range of other impedimetric nucleic acid sensors that permit label-free detection of hybridization using a range of nanoparticles modified with redox mediators and conducting polymers (reviewed by Bonanni \& del Valle, 2010).

An indirect approach to determine the degree of hybridization is through electrooxidation of guanine residues (Palecek \& Bartosik, 2012). The principle of the assay is to oxidize the free (unpaired) guanine groups thereby leading to a decrease if full hybridization between immobilized probe and target DNA. Transition metals along with carbon nanotubes have found utility in this area primary through enhancing the rate of electron transfer (Palecek \& Bartosik, 2012).

Optical methods for monitoring probe hybridization using nanomaterials vary in complexity. For example, a sensor for E. coli 0157:H7 and Salmonella has been reported based on the immobilization of aptamers onto the surface of gold nanoparticles ( Pieta et al., 2013 and Wu et al., 2012). In one example, upon binding of the pathogen target there is a visible change of the nanobeads from red to blue. The sensor is claimed to be $100 \%$ selective in detecting pathogens although the sensitivity is relatively low with a detection limit of $4 \log \mathrm{cfu} / \mathrm{g}$ (Paniel et al., 2013).

Quantum dots refer to structures $<10 \mathrm{~nm}$ fabricated from materials taken from groups II-VI and III-V of the periodic table. The main interest in quantum dots is derived from the electrical and optical properties. At its most basic, quantum dots absorb photons that generate exciton thereby releasing electromagnetic energy in the form of photoluminescence (Pisanic li, Zhang, \& Wang, 2014). The 
wavelength of the emission of quantum dots is dependent on size and hence can be controlled or tuned. Modulation of emission spectra opens the way for multiple target analysis with the added advantage of intense fluorescence compared to standard fluorophores. Quantum dots have been extensively used for immunoassay as a substitute for enzyme labels. In this format the advantages of quantum dots were to omit an assay step and achieve multiple pathogen screening in a single assay (Pisanic li et al., 2014). With respect to biosensors, one of the most interesting properties of quantum dots is Forster resonance energy. Here, the generation of excitons (hence emission light) can be enhanced by closely located fluorescent molecules. This gave rise to Forster resonance energy transfer (FRET) based sensors with the most widely used example being Real Time-PCR. The same principle has been used to develop a self-contained DNA sensor (Pisanic li et al., 2014). In one format the DNA capture probes are labeled with a fluorescent reporter and another with a biotin label ( $\underline{\text { Fig. 3 }}$ ). The probes are designed to hybridize to different parts of the target DNA, thereby imparting a fluorophore at one end of the strand and a biotin group at the other. Quantum dots modified with streptavidin are then added which bind the biotin moiety thereby generating the FRET (C. Y. Zhang, Yeh, Kuroki, \& Wang, 2005). The complex thereby emits light through photobioluminescence and FRET thereby generating an intense signal. In the absence of target DNA the fluorophore will be spatially distant from the quantum dot to generate the intense signal above background. In a further assay, the emittant quenching effect of quantum dots by transition metal nanoparticles have been described in a process referred to as nanosurface energy transfer (NSET) or dipole to metal particle transfer (DMPET). In one example, quantum dots are complexed with gold nanoparticles through aptamers. Upon binding of the target to the aptamer the quantum dot complex is released thereby no longer quenched by the metal nanobead and so leading to an increase in fluorescence (Pisanic li et al., 2014). There are several further examples FRET and NSET/DMPET based assays with the common feature of being high sensitivity and requiring less user input compared with traditional hybridization assays (Gholami \& Kompany-Zareh, 2013). 
a

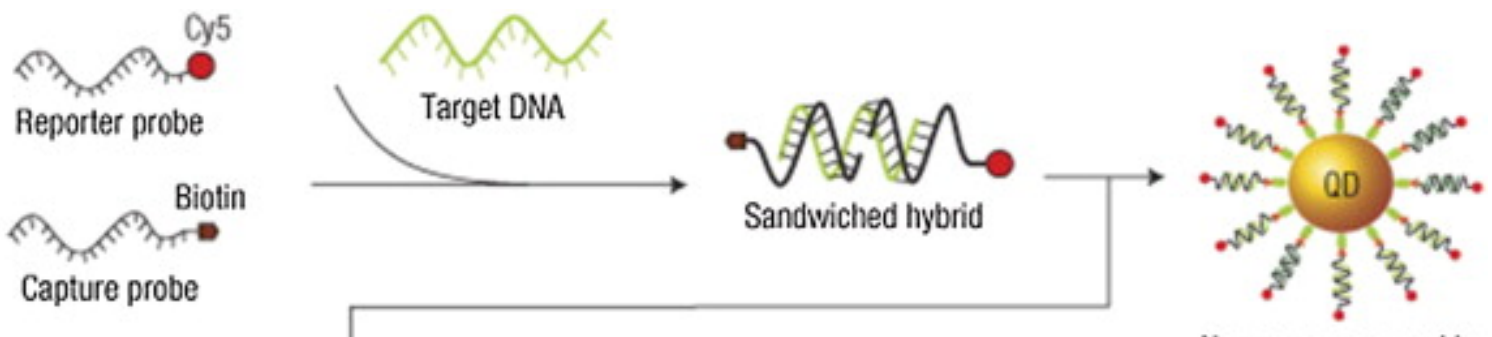

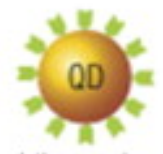

Streptavidin-conjugated OD

b

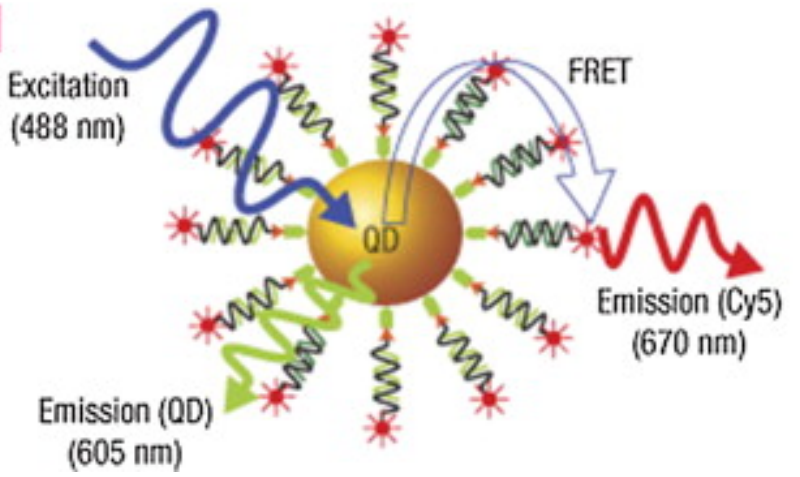

Nanosensor assembly

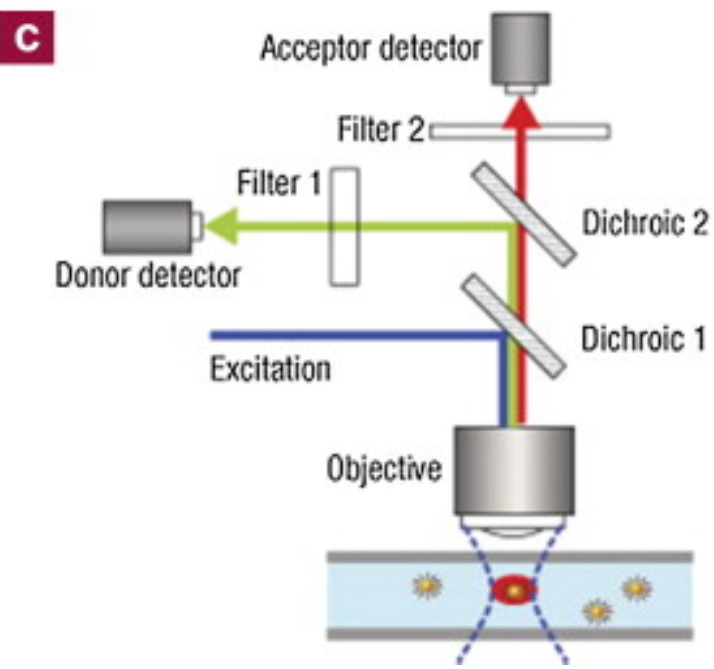

Fig. 3.

Schematic for a DNA sensor based on quantum do labeled hybridization assay. The capture probe is modified with biotin and reporter with Cy5 fluorescent label (a). The capture and reporter probe hybridize with target DNA. The complex binds to streptavidin modified quantum dots. The complex is illuminated with light $(488 \mathrm{~nm})$ that induces photoluminescence and FRET of the QD and Cy5 respectively (b). The different wavelength emitted light is detected via a microfluid-type device with illumination using an argon laser ( $488 \mathrm{~nm}$ ) using duel photodiodes (c) (Reprinted with permission from Zhang et al., 2005).

\section{Figure options}

Trends in biosensors for assessing the safety and quality of foods

Despite the wealth of literature on biosensors for detection of hazards and quality markers in foods there are relatively few examples where complete analysis has been performed using the sensor device. For example, biosensors for pathogen detection include enrichment steps which go against the philosophy of on-site testing. Therefore, the following sections provide examples of nanoparticle biosensors that have been applied to detect safety and quality markers directly in food matrices. It is not an exhaustive list but illustrates the possibilities and challenges in sensors directed towards onsite testing of foods (Table 3 ).

Table 3.

Examples of biosensors for screening for pathogens, toxins and allergens products in food matrices. 


\begin{tabular}{|c|c|c|c|c|}
\hline Target & Sensor description & $\begin{array}{l}\text { Food } \\
\text { matrix }\end{array}$ & $\begin{array}{l}\text { Detection } \\
\text { limit/time }\end{array}$ & Source \\
\hline \multicolumn{5}{|l|}{ Pathogen } \\
\hline \multirow[t]{3}{*}{$\begin{array}{l}\text { L. } \\
\text { monocytogen } \\
\text { es }\end{array}$} & $\begin{array}{l}\text { IMS; impedimetric } \\
\text { microfluidic device }\end{array}$ & $\begin{array}{l}\text { Ground } \\
\text { beef }\end{array}$ & $4 \log \mathrm{cfu} / \mathrm{g}$ & $\underline{\text { Kanayevaet al., }}$ \\
\hline & & Milk & $20 \mathrm{~min}$ & \\
\hline & & $\begin{array}{l}\text { Lettuce } \\
\text { rinse }\end{array}$ & & \\
\hline \multirow[t]{2}{*}{$\begin{array}{l}\text { E. } \\
\text { coli 0157:H7 }\end{array}$} & IMS: MALDI-MS & $\begin{array}{l}\text { Ground } \\
\text { beef }\end{array}$ & $6 \mathrm{log} \mathrm{cfu} / \mathrm{g}$ & $\begin{array}{l}\text { Ochoa \& } \\
\underline{\text { Harrington, }} \\
\underline{2005}\end{array}$ \\
\hline & & & $30 \mathrm{~min}$ & \\
\hline \multirow[t]{2}{*}{$\begin{array}{l}\text { E. } \\
\text { coli 0157:H7 }\end{array}$} & $\begin{array}{l}\text { IMS: Fluorescent } \\
\text { immunoassay }\end{array}$ & $\begin{array}{l}\text { Ground } \\
\text { beef }\end{array}$ & $5 \log \mathrm{cfu} / \mathrm{g}$ & $\underline{\text { Aydin et al., }}$ \\
\hline & & Milk & $3 \mathrm{~h}$ & \\
\hline \multirow[t]{2}{*}{$\begin{array}{l}\text { E. } \\
\text { coli 0157:H7 }\end{array}$} & $\begin{array}{l}\text { Filtration: } \\
\text { Electrochemiluminescen } \\
\text { ce }\end{array}$ & $\begin{array}{l}\text { Spent } \\
\text { produce } \\
\text { wash } \\
\text { water }\end{array}$ & $\begin{array}{l}0.36 \log \mathrm{cfu} / \\
\mathrm{ml}\end{array}$ & $\begin{array}{l}\frac{\text { Magana, }}{\text { Schlemmer, }} \\
\text { Leskinen, } \\
\text { Kearns, \& Lim, } \\
\underline{2013}\end{array}$ \\
\hline & & & $2 \mathrm{~h}$ & \\
\hline $\begin{array}{l}E . \\
\text { coli 0157:H7 }\end{array}$ & $\begin{array}{l}\text { IMS: Quantum dot } \\
\text { multiplex immunoassay }\end{array}$ & $\begin{array}{l}\text { Rinse } \\
\text { solution } \\
\text { s from } \\
\text { ground } \\
\text { beef, } \\
\text { poultry } \\
\text { and } \\
\text { lettuce }\end{array}$ & $1 \mathrm{log} \mathrm{cfu} / \mathrm{ml}$ & $\begin{array}{l}\text { Wang, Li, Wang, } \\
\underline{\text { \& Slavik, } 2011}\end{array}$ \\
\hline Salmonella & & & $2 \mathrm{~h}$ & \\
\hline \multicolumn{5}{|l|}{$\begin{array}{l}\text { L. } \\
\text { monocytogen } \\
\text { es }\end{array}$} \\
\hline S. aureus & $\begin{array}{l}\text { IMS: Filtration: } \\
\text { Colorimetric assay }\end{array}$ & Milk & $5 \log \mathrm{cfu} / \mathrm{ml}$ & $\underline{\text { Sung et al., } 2013}$ \\
\hline
\end{tabular}




\begin{tabular}{|c|c|c|c|c|}
\hline Target & Sensor description & $\begin{array}{l}\text { Food } \\
\text { matrix }\end{array}$ & $\begin{array}{l}\text { Detection } \\
\text { limit/time }\end{array}$ & Source \\
\hline & & & $40 \mathrm{~min}$ & \\
\hline \multicolumn{5}{|l|}{ Toxins } \\
\hline \multirow[t]{2}{*}{$\begin{array}{l}\text { Botulism } \\
\text { neurotoxin A } \\
\text { B }\end{array}$} & $\begin{array}{l}\text { Au nanoparticles: Lateral } \\
\text { flow immunoassay }\end{array}$ & Milk & $5-10 \mathrm{ng}$ & $\begin{array}{l}\frac{\text { Ching, Lin, }}{\text { McGarvey, }} \\
\text { Stanker, \& } \\
\text { Hnasko, 2012 }\end{array}$ \\
\hline & & $\begin{array}{l}\text { Apple } \\
\text { juice }\end{array}$ & & \\
\hline Cholera toxin & $\begin{array}{l}\text { IMS: Immunoassay } \\
\text { microfluidic cell }\end{array}$ & Water & $1.1 \mathrm{pg} / \mathrm{ml}$ & $\frac{\text { Shlyapnikovet al }}{2012}$ \\
\hline $\begin{array}{l}\text { ETEC } \\
\text { enterotoxin }\end{array}$ & & Meat & $10 \mathrm{~min}$ & \\
\hline $\begin{array}{l}\text { Toxic shock } \\
\text { syndrome } \\
\text { toxin }\end{array}$ & & Milk & & \\
\hline Botulism toxin & Quantum dot IMS: FRET & Water & $1 \mathrm{pM}$ & $\underline{\underline{2009}}$ \\
\hline Citrinin & $\begin{array}{l}\text { Au nanobeads: } \\
\text { Electrochemical ELISA } \\
\text { microfluidic }\end{array}$ & Rice & $0.5 \mathrm{ng} / \mathrm{ml}$ & $\begin{array}{l}\frac{\text { Arevalo, }}{\text { Granero, }} \\
\text { Fernandez, } \\
\text { Raba, \& Zon, } \\
\underline{2011}\end{array}$ \\
\hline \multirow[t]{5}{*}{ Aflatoxin $B_{1}$} & $\begin{array}{l}\text { Impedimetric } \\
\text { immunosensor }\end{array}$ & Peanut & $1 \mathrm{ng} / \mathrm{g}$ & Zhou et al., 2012 \\
\hline & & Rice & & \\
\hline & & Milk & & \\
\hline & & Flour & & \\
\hline & & $\begin{array}{l}\text { Soybea } \\
n\end{array}$ & & \\
\hline $\begin{array}{l}\text { Deoxynivaleno } \\
\text { I }\end{array}$ & $\begin{array}{l}\text { Quantum Dot } \\
\text { Immunoassay }\end{array}$ & Maize & $5 \mu \mathrm{g} / \mathrm{l}$ & $\begin{array}{l}\text { Speranskayaet al } \\
.2014\end{array}$ \\
\hline
\end{tabular}




\begin{tabular}{|c|c|c|c|c|}
\hline Target & Sensor description & $\begin{array}{l}\text { Food } \\
\text { matrix }\end{array}$ & $\begin{array}{l}\text { Detection } \\
\text { limit/time }\end{array}$ & Source \\
\hline Soy Protein & $\begin{array}{l}\text { Immunoassay Nitrile } \\
\text { Blue encapsulated silca } \\
\text { nanoparticle labels }\end{array}$ & Yoghurt & $0.05 \mathrm{mg} / \mathrm{l}$ & $\begin{array}{l}\frac{\text { Godoy-Navajas, }}{\text { Caballos, \& }} \\
\underline{\text { Gomez-Hens, }} \\
\underline{2011}\end{array}$ \\
\hline Casein & $\begin{array}{l}\text { Antibody modified gold } \\
\text { nanoparticle carbon } \\
\text { nanotube electrode: } \\
\text { DVP }\end{array}$ & Cheese & $50 \mathrm{~g} / \mathrm{l}$ & $\begin{array}{l}\text { Q. Caoet al., } \\
\underline{2011}\end{array}$ \\
\hline Shrimp & Antibody modified QCM & Water & $33 \mathrm{mg} / \mathrm{l}$ & $\underline{\text { Pilolli et al., }}$ \\
\hline Sulfite & $\begin{array}{l}\text { Sulfite oxidase: ferric } \\
\text { oxide: gold electrode: } \\
\text { Amperometry }\end{array}$ & Wine & $6 \mathrm{mg} / \mathrm{l}$ & $\frac{\text { Rawal, Chawla, }}{\text { \& Pundir, } 2012}$ \\
\hline
\end{tabular}

\section{$\underline{\text { Table options }}$}

Trends in foodborne pathogen detection

An impedimetric immunosensor has been described for L. monocytogenes whereby the pathogen is captured and concentrated using IMS then $20 \mu$ l of the captured beads are flowed over a series of interdigitated electrodes ( Kanayeva et al., 2012). The presence ofListeria resulted in a change in impedance at $102 \mathrm{~Hz}$ although was not found to be concentration dependent. In simple buffer solution the detection limit for the assay was $3 \log \mathrm{cfu} / \mathrm{ml}$. However, in lettuce rinse samples, milk or homogenated ground beef samples the sensitivity of the assay was decreased with a detection limit of $4 \log \mathrm{cfu} / \mathrm{ml}$ with high variation in sensor response being observed (Kanayeva et al., 2012). The sensor response was significantly lower when Listeria was introduced into beef homogenate compared to lettuce rinse solution and milk. The relatively low sensitivity of the assay was attributed to interference of Listeria capture due to protein/fat in the sample along with the small sample volumes that could be processed by the microfluidic system ( Kanayeva et al., 2012).

A sensor has been described for E. coli O157: $\mathrm{H} 7$ where the target is captured on antibody modified paramagnetic nanobeads then detected via impedance spectroscopy ( Varshney, Li, Srinivasan, \& Tung, 2007). Although the assay time was only $35 \mathrm{~min}$ the lower detection limit was 4-5 log cfu/g which is above that required for ground beef testing that requires detection of $1 \mathrm{cfu} / 25 \mathrm{~g}$ (Table 1 ).

An Staphylococcus aureus biosensor was described based on paramagnetic beads (micron dimension) modified with gold nanoparticles with immobilized anti-S. aureusantibodies ( 2013). The inclusion of gold nanoparticles on the larger paramagnetic bead was thought to enhance the capture efficacy of $S$. aureus from the milk matrix. The captured cells were concentrated by placing under a magnet then passing through a micro-filter that retains bound beads with unbound passing through. The fluorescence of the gold particles were used to quantify the number of cells captured. Although rapid (40 min assay time) the sensor exhibited poor sensitivity with a lower detection limit of $5 \mathrm{log} \mathrm{cfu} / \mathrm{ml}$ ( Sung et al., 2013). 
An E. coli 0157:H7 sensor based on an initial IMS capture step followed by tyramide signal amplification (TySA) ELISA ( Aydin et al., 2014). TySA is a signal amplification method based on horseradish peroxidase deposition of tyamide conjugates thereby increasing fluorescent label loading. The assay was verified by screening ground beef homogenates and milk inoculated with $E$. coli 0157:H7 along with other potential interferent bacterial types. The assay was selective although recovery of the pathogen in food matrices using IMS was 1 log cfu/ml lower than that observed in simple buffer solution ( Aydin et al., 2014).

Silica nanoparticles essentially provides an optical transparent, biocompatible, functionalized, carrier for quantum dots and other fluorescent dyes (Majdalawieh et al., 2014). In one example, RuBpy encapsulated in $60 \mathrm{~nm}$ silica nanoparticles are conjugated to anti-E. coli 0157:H7 antibodies that greatly enhanced the sensitivity of the immunoassay over conventional fluorescent based immunoassays. By using a 384-well format the level of sensitivity of E. coli 0157:H7 in ground beef was 1-400 cells (X. J.Zhao et al., 2004).

The importance of sample preparation technique is underlined by an example of a non-culture based techniques for detecting E. coli $\mathrm{O} 157: \mathrm{H} 7$ in spent leafy green wash water. Here, filtration was applied to concentrate the target from $50 \mathrm{~L}$ of water. The concentrated sample in $400 \mathrm{ml}$ of retentate was subject to electrochemiluminescence assay using antibodies labeled with silica encapsulated ruthenium (II) tribipyridal ( Magana, et al., 2013). The combined filtration and immunoassay could detect low levels of the target $(0.39 \mathrm{log} \mathrm{cfu} / \mathrm{ml})$ introduced into the $50 \mathrm{~L}$ of sample water. Although the system does stretch the definition of nanobiosensor it demonstrates the need for those interested in detecting foodborne pathogens to consider sample size rather than drive for miniaturization as in the health care sector.

Trends in detection of toxins in foods

Microbial toxins in some aspects are easier to detect than the cell that produced it. Although the actual toxin produced is in the order of ng there are multiple copies thereby enabling sensitive detection. The majority of sensors developed have been based on immunoassay coupled with immunocapture or flow through microfluidics with the antibodies immobilized on the sensor surface (Ching et al., 2012). The main innovation has been the adoption of microfluidic and electrochemical or electrical detection derived from the classic ELISA assays (Tothill, 2011).

The development of biosensors for mycotoxin detection has been a greater challenge. Not only is there a greater degree of diversity (more than 500 mycotoxin types have been considered significant) but also extracting low levels from food matrices can be challenging (Berthiller et al., 2014 and Pereira et al., 2014). With respect to the latter the majority of reports on biosensors for mycotoxin detection have been limited to using artificially spiked samples as opposed to considering the extraction step from the original food matrix. In routine mycotoxin analysis the extraction from food matrices such as grain is achieved through an initial solvent extraction, centrifugation or filtration followed by solid phase extraction (Tothill, 2011). However, nanoparticles have been applied in Magnetic Solid Phase Extraction (MSPE) that can be used in place of centrifugation and filtration steps (McCullum, Tchounwou, Ding, Liao, \& Liu, 2014). In one example the surface of ferric oxide nanobeads modified with polydopamine onto which the aflatoxin in the sample binds. Separation from the sample matrix can be achieved through applying a magnetic field akin to IMS. By using the optimized protocol it was possible to achieve $59 \%$ recovery of aflatoxin AF and $89 \%$ recovery of aflatoxin B-1 in $1 \mathrm{~L}$ volumes of red wine with minimal number of steps (McCullum et al., 2014). With respect to biosensors, an impedimetric sensor for aflatoxin B1 has been described based on graphene/conducting polymer/gold nanoparticles modified with antibodies (Zhou et al., 2012). 
Upon binding of the aflatoxin target there was a concentration dependent charge transfer resistance. The sensor could detect aflatoxin introduced into a range of food matrices (peanut, rice, milk, flour and soybean) in ng/g levels (Zhou et al., 2012). The gold nanoparticles aided enhanced sensitivity of the sensor through increasing the charge transfer kinetics of the reporting conducting polymer film (Zhou et al., 2012). In a more conventional format, an optical based immunoassay has been described whereby quantum dot anti-DON antibodies were applied to detect the mycotoxin in diluted maize extract (Speranskaya et al., 2014). The unique feature of the sensor was the poly(maleic anhydridealt-1-octadecene) coating that retained fluorescence of the quantum dot reporter thereby enabling detection limits of $500 \mu \mathrm{g} / \mathrm{l}$. Apart from the aforementioned sensors, there has been relatively little work on the application of nanoparticles in mycotoxin detection directly from food matrices. A point noted by a recent review byTothill (2011).

Trends in allergen detection

For detection of allergens a biosensor should meet or exceed performance of laboratory based techniques (Faeste et al., 2011). Optical sensors based on gold nanoparticles or Nile Blue encapsulated in silica nanobeads have been applied as labels in fluorimetric immunoassays (GodoyNavajas et al., 2011). The assay was evaluated for detection of soy protein and found to have comparable performance to that of standard ELISA tests with the benefit of having less steps (Godoy-Navajas et al., 2011).

Electrochemical biosensors for allergen detection have been described. In one example, an electrode prepared from carbon nanotubes modified with poly-arginine and gold nanoparticles with immobilized ant-casein antibodies has been described (Cao et al., 2011). The principal of the assay was to capture the casein via antibody binding that reduced the redox peak from ferricyanide as detected through differential pulsed voltammetry. The sensor was reported to have high sensitivity and selectivity. The same sensor format have been applied for detecting other allergens with equal success (Pilolli, Monaci, \& Visconti, 2013). Other sensor formats employing nanoparticles includes a QCM coated with antibody modified gold nanoparticles for the detection of shrimp and gliadin protein (Pilolli et al., 2013).

$\beta$-adrenergic agonist (for example, ractopamine, clenbuterol and salbutamol) is an example of growth promoters used in animal production that can be potentially recovered in meat. To simultaneously detect rectopamine, clenbuterol and salbutamol in meat, an antibody modified silver-palladium alloy nanoparticle biosensor was developed (H.Wang et al., 2013a and Wang et al., 2013b). The adopted screen printing technology enhanced the simultaneous detection of the residues without cross-talk and with detection limit of $1.52 \mathrm{pg} / \mathrm{ml}$. Multiplexing assay was able to analyze the $3 \beta$-adrenergic residues from up to $10 \mathrm{~g}$ of pork sample ( $\mathrm{H}$. Wang et al., 2013a and Wang et al., 2013b; Z.Wang et al., 2013).

Biosensors for directed detection of allergens in foods is well advanced and it can be envisaged that devices based on nanoparticles are close to commercialization. In addition, given the sensitivity of persons with allergen sensitivity it can be predicted that point-of-use biosensor devices based on nanoparticle technology will find widespread utility (Pilolli et al., 2013).

Food quality and shelf-life prediction sensors

Xanthine is a breakdown product of purines that can be used to predict the shelf-life of meat and fish (Devi, Yadav, \& Pundir, 2012). A xanthine sensor has been described based on chitosan modified $\mathrm{ZnO}$ nanoparticles on a multiwall carbon nanotube scaffold within a polyaniline matrix onto which the xanthine oxidase was covalently bound. The modified electrode exhibited high current densities 
by virtue of the large surface area provided by using nanoparticles. The sensor had a lower detection limit of $0.1 \mathrm{mM}$ xanthine and could be used to monitor the concentration of the degredative metabolite in fish without interference from background constituents (Devi et al., 2012). A further xanthine sensor utilizing xanthine oxidase immobilized onto silver nanoparticles has also been reported (Devi, Batra, Lata, Yadav, \& Pundir, 2013). The authors suggested that the use of silver nanoparticles enhanced the stability of the enzyme that retained activity when stored at room temperature for 60 days (Devi et al., 2013).

In many sectors of the food industry the final quality assessment of products is through trained sensory panels which not only are expensive, could be subjective and also require highly trained personnel. There has been a sustained interest in removing the human element from the equation to ensure consistency of analysis and also less reliant on having to employ sensory specialist. Sensors have been fabricated based on MOSFET where taste receptors (e.g. for bitterness) are synthesized then immobilized on the surface of polypyrrole modified carbon nanotubes. Upon binding of the compounds associated with bitterness of the sample there is a reorientation of the polypyrrole that is transduced into an electrical signal as recoded by an increase in drain current. The system has been tested in a range of beverages and can detect down to $1 \mathrm{fM}$ with high degree of selectivity (Song et al., 2013). Less specific sensing strategies have used $\mathrm{ZnO}$ or titanium dioxide nanoparticles to detect volatiles such as ethanol or oxygen respectively (Bogue, 2014).

Polyaniline boronic acid conducting polymer nanoparticle based electronic nose and carbon dioxide sensor has been demonstrated for use in incipient or ongoing spoilage in storage of grain (Neethirajan, Freund, \& Jayas, 2013).

From a nanotechnology perspective the area of artificial sensing is an emerging area with most active research being focused on developing sensor arrays along with data analysis (e.g. neural networks) programs. Still, artificial noses have found utility in quality control, authenticity, shelf-life prediction, in addition to process monitoring. Example of applications range from verifying the quality of grain, monitoring the progress of wine fermentations, cheese ripening and spoilage detection of meat (Sliwinska et al., 2014).

Future outlook of biosensors based on nanoparticles

There have been major advances in the nanotechnology field especially with respect to nanoparticles. By working at the nanoscale it will be feasible to develop devices capable of screening multiple analytes of relevance to food safety and quality. The ability to sample and rapidly screen samples in an integrated sensor offers the route to on-line or real-time testing. Yet, the commercial demand for such sensors in the food industry remains open to question. The history of biosensors has illustrated that advances in the laboratory do not translate into commercial application. Although many sensors are focused on detection of pathogens it is more likely those directed towards detecting allergens, monitoring fermentations and product quality would be more adopted by industry. The underlying reasons for such a view is based on economics with respect to avoiding allergens, fermentation failures or accepting a bad batch of product/raw material. In this respect it is interesting to note that relatively few sensors based on nanoparticles have been described for fermentation monitoring. Yet, great deals of effort has been expended on pathogen sensors and despite elegant designs, are ultimately limited by the small sample volumes. Such limitations can be overcome by designing novel sample preparation technologies to concentrate targets from sample volumes encountered in routine food testing.

Acknowledgments 
The authors sincerely thank the Natural Sciences and Engineering Research Council of Canada (400929), National Centre of Food Protection \& Defense (DHS 4392) and the Ontario Ministry of Agriculture and Food (200154) for funding this study.

\section{Figures:}

Fig. 1.

Transmission electron microscopy monographs of nanoparticles commonly applied in biosensor fabrication.

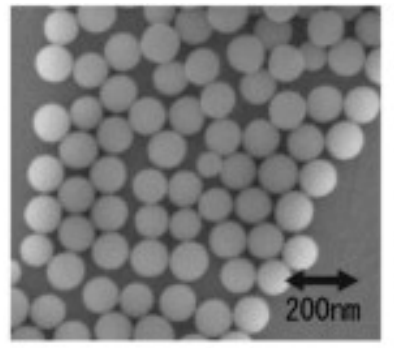

Fluorescent Silica

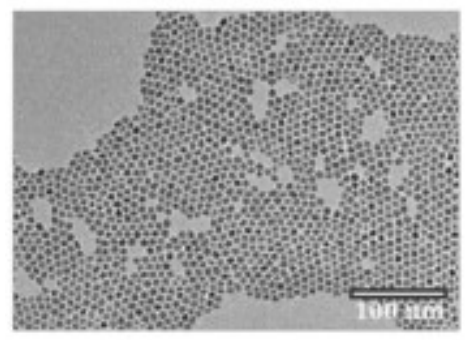

Quantum Dots

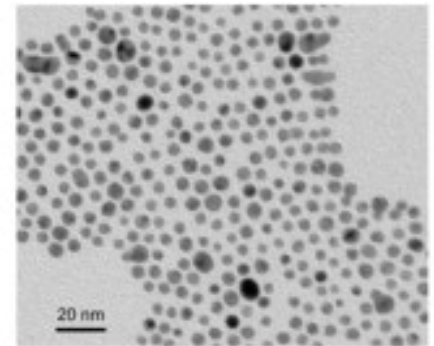

Gold Nanobeads

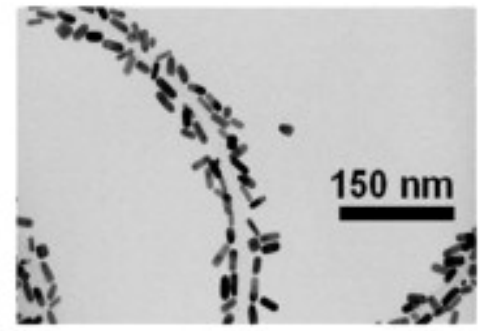

Carbon Nanotubes

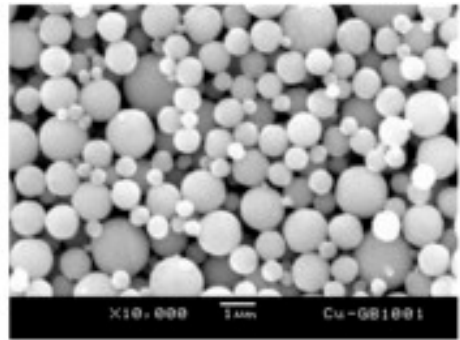

Zinc Oxide Nanobeads

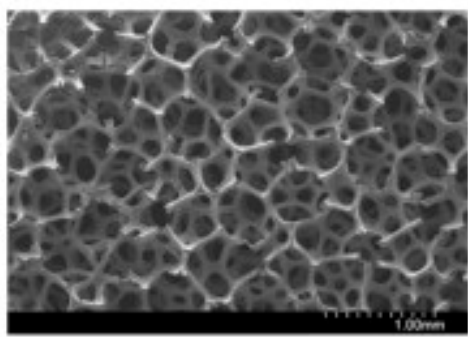

Graphene

Fig. 2.

Schematic representation of generation of $\mathrm{Fe}_{3} \mathrm{O}_{4}$ nanoparticles modified with ATRP to fabricate Tobacco Mosaic Virus surface-imprinted polymer. Nanobeads (in black) are functionalized with a silica layer (in gray) and the coated silica layer beads grafted carbon-halide bond $(-\mathrm{CBr})$ to form the ATRP initiator. Polymerization of the monomer ( $\mathrm{N}$-isopropylacrylamide) and assistant monomer (acrylamide) along with cross-linker ( $\mathrm{N}, \mathrm{N}$-methylenebisacrylamide) is initiated in presence of TMV template. The template is removed following the imprinting process to yield the TMV-imprinted nanobeads (Sun, 2013). 


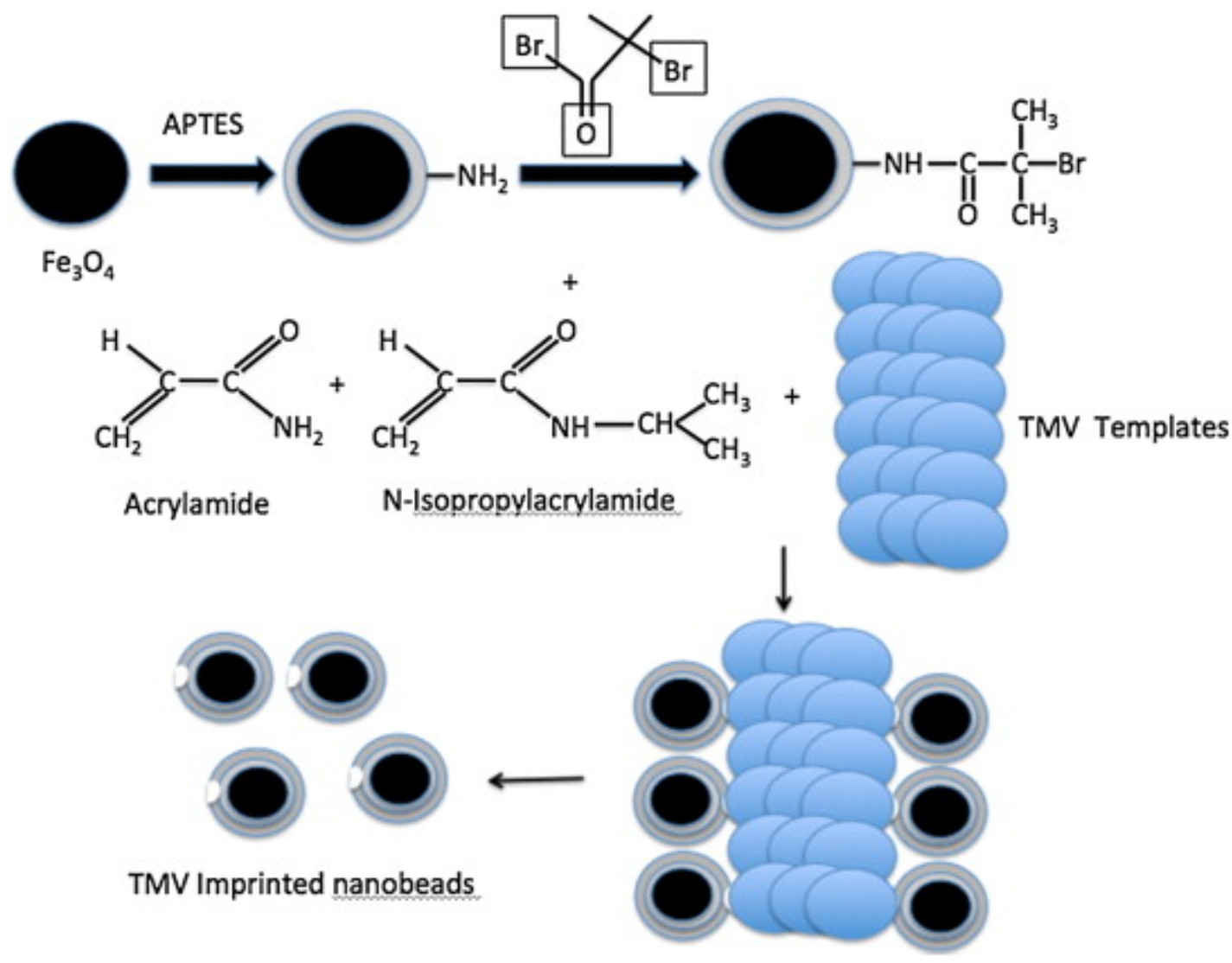

Fig. 3.

Schematic for a DNA sensor based on quantum do labeled hybridization assay. The capture probe is modified with biotin and reporter with Cy5 fluorescent label (a). The capture and reporter probe hybridize with target DNA. The complex binds to streptavidin modified quantum dots. The complex is illuminated with light $(488 \mathrm{~nm})$ that induces photoluminescence and FRET of the QD and Cy5 respectively (b). The different wavelength emitted light is detected via a microfluid-type device with illumination using an argon laser (488 nm) using duel photodiodes (c) (Reprinted with permission from Zhang et al., 2005). 
a

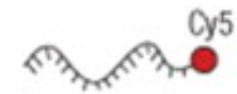

Reporter probe

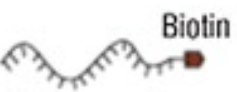

Capture probe

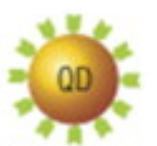

Streptavidin-conjugated 00

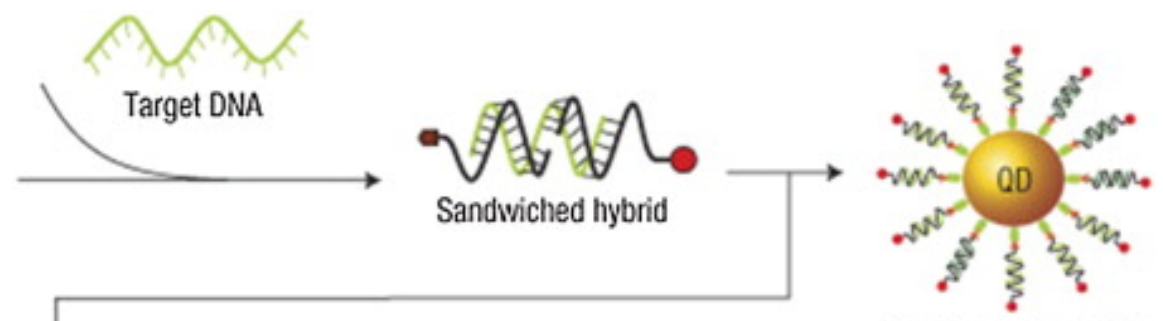

Nanosensor assembly

C

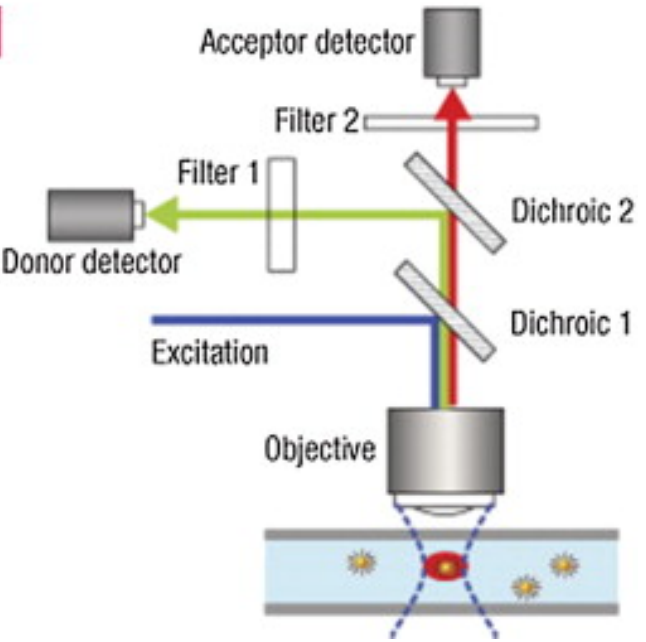

b

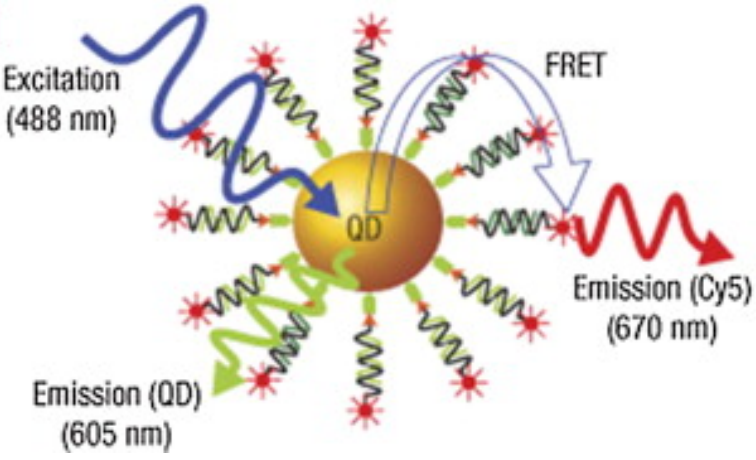

\section{References:}

Ahmed, M. U., Saaem, I., Wu, P. C., \& Brown, A. S. (2014).

Personalized diagnostics and biosensors: a review of the biology and technology needed for personalized medicine. Critical

Reviews in Biotechnology, 34(2), 180e196.

Anonymous. (2005). Enumeration of Staphylococcus aureus in

foodsIn Compendium of analytical methods. MFHPB-21. http://

www.hc-sc.gc.ca/fn-an/res-rech/analy-meth/microbio/volume2- 
eng.php Accessed 17.07.14.

Anonymous. (2007). Enumeration of Enterobacteriaceae species in food and environmental samples using $3 \mathrm{M}$ ? Petrifilm? Enterobacteriaceae count platesIn Compendium of analytical methods. http://www.hc-sc.gc.ca/fn-an/res-rech/analy-meth/ microbio/volume3-eng.php Accessed 17.07.14. Anonymous. (2012a). Screening bottled water (water in sealed containers) for the presence of indicator and pathogenic bacterialn Compendium of analytical methods. MFLP-60. http://www.hc-sc. gc.ca/fn-an/res-rech/analy-meth/microbio/volume3-eng.php Accessed 17.07.14.

Anonymous. (2012b). Enumeration of Escherichia coli in foods by a direct plating (DP) methodIn Compendium of analytical methods. MFHPB-27. http://www.hc-sc.gc.ca/fn-an/res-rech/analy-meth/ microbio/volume2-eng.php Accessed 17.07.14. Anonymous. (2013). 40 CFR 150.17 protection of the environment. Code of Federal Regulations. Pub Office of the Federal National Archives and Records of Administration.

Antiochia, R., \& Gorton, L. (2014). A new osmium-polymer modified screen-printed graphene electrode for fructose detection (Article). Sensors and Actuators B e Chemical, 195, 287e293.

Arevalo, F. J., Granero, A. M., Fernandez, H., Raba, J., \& Zon, M. A. (2011). Citrinin (CIT) determination in rice samples using a micro fluidic electrochemical immunosensor. Talanta, 83(3), 966e973. Arugula, M. A., \& Simonian, A. (2014). Novel trends in affinity biosensors: current challenges and perspectives (Review). Measurement Science \& Technology, 25(3), 22.

Augustin, J.-C. (2011). Challenges in risk assessment and predictive microbiology of foodborne spore-forming bacteria. Food Microbiology, 28(2), $209 \mathrm{e} 213$.

Aydin, M., Herzig, G. P. D., Jeong, K. C., Dunigan, S., Shah, P., \& 
Ahn, S. (2014). Rapid and sensitive detection of Escherichia coli O157:H7 in milk and ground beef using magnetic bead based immunoassay coupled with tyramide signal amplification. Journal of Food Protection, 77(1), 100e105.

Berthiller, F., Burdaspal, P. A., Crews, C., Iha, M. H., Krska, R., Lattanzio, V.M. T., et al. (2014). Developmentsinmycotoxin analysis: an update for 2012e2013. World Mycotoxin Journal, 7(1), 3e33. Blecher, K., \& Friedman, A. (2012). Nanotechnology and the diagnosis of dermatological infectious disease. Journal of Drugs in Dermatology, 11(7), 846e851.

Bogue, R. (2014). Nanomaterials for gas sensing: a review of recent research. Sensor Review, 34(1), 1 e8.

Bonanni, A., \& del Valle, M. (2010). Use of nanomaterials for impedimetric DNA sensors: a review (Review). Analytica Chimica Acta, 678(1), 7e17.

Bosilevac, J. M., Guerini, M. N., Brichta-Harhay, D. M., Arthur, T. M., \& Koohmaraie, M. (2007). Microbiological characterization of imported and domestic boneless beef trim used for ground beef. Journal of Food Protection, 70(2), 440e449.

Cai, J., Ai, S., Yin, H., \& Shi, W. (2009). Preparation of DNA electrochemical biosensor based on PAMAM/poly(2,6pyridinedicarboxylic acid) composite film and its application to the detection to avian virus gene. Acta Chimica Sinica, 67(19), 2227 e2232.

Cao, J., Sun, T., \& Grattan, K. T. V. (2014). Gold nanorod-based localized surface plasmon resonance biosensors: a review. Sensors and Actuators B e Chemical, 195, 332e351.

Cao, Q., Zhao, H., Yang, Y. M., He, Y. J., Ding, N., Wang, J., et al. (2011). Electrochemical immunosensor for casein based on gold nanoparticles and poly(L-Arginine)/multi-walled carbon nanotubes composite film functionalized interface. Biosensors \& 
Bioelectronics, 26(8), 3469e3474.

Chen, S., Yuan, R., Chai, Y., \& Hu, F. (2013). Electrochemical sensing of hydrogen peroxide using metal nanoparticles: a review.

Microchimica Acta, 180(1e2), 15e32.

Ching, K. H., Lin, A., McGarvey, J. A., Stanker, L. H., \&

Hnasko, R. (2012). Rapid and selective detection of botulinum

neurotoxin serotype-A and $-B$ with a single

immunochromatographic test strip. Journal of Immunological

Methods, 380(1e2), $23 \mathrm{e} 29$.

Cipolatti, E. P., Silva, M. J. A., Klein, M., Feddern, V., Feltes, M. M. C.,

Oliveira, J. V., Ninow, J. L., \& de Oliveira, D. (2014). Current status

and trends in enzymatic nanoimmobilization. Journal of

Molecular Catalysis B-Enzymatic, 99, 56e67.

Crowley, E., Bird, P., Flannery, J., Benzinger, M. J., Jr., Fisher, K., Boyle, M., et al. (2014). Evaluation of VIDAS (R) UP Listeria assay

(LPT) for the detection of Listeria in a variety of foods and environmental surfaces: First Action 2013.10. Journal of AOAC International, 97(2), 431e441.

Das, A. P., Kumar, P. S., \& Swain, S. (2014). Recent advances in biosensor based endotoxin detection. Biosensors \& Bioelectronics, 51, $62 \mathrm{e} 75$.

Deng, S. Y., Jian, G. Q., Lei, J. P., Hu, Z., \& Ju, H. X. (2009). A glucose biosensor based on direct electrochemistry of glucose oxidase immobilized on nitrogen-doped carbon nanotubes. Biosensors \& Bioelectronics, 25(2), 373e377.

Desmarchelier, J. M., \& Ren, Y. L. (1999). Analysis of fumigant residues e a critical review. Journal of AOAC International, 82(6), $1261 \mathrm{e} 1280$.

Devi, R., Batra, B., Lata, S., Yadav, S., \& Pundir, C. S. (2013). A method for determination of xanthine in meat by amperometric biosensor based on silver nanoparticles/cysteine modified Au electrode.

Process Biochemistry, 48(2), 242e249. 
Devi, R., Yadav, S., \& Pundir, C. S. (2012). Amperometric determination of xanthine in fish meat by zinc oxide nanoparticle/ chitosan/multiwalled carbon nanotube/polyaniline composite film bound xanthine oxidase. Analyst, 137(3), 754e759.

Ding, X. C., \& Heiden, P. A. (2014). Recent developments in molecularly imprinted nanoparticles by surface imprinting techniques. Macromolecular Materials and Engineering, 299(3), $268 \mathrm{e} 282$. Espineira, M., Herrero, B., Vieites, J. M., \& Santaclara, F. J. (2010). Validation of end-point and real-time PCR methods for the rapid detection of soy allergen in processed products. Food Additives and Contaminants Part A e Chemistry Analysis Control Exposure \& Risk Assessment, 27(4), 426e432.

Faeste, C. K., Ronning, H. T., Christians, U., \& Granum, P. E. (2011). Liquid chromatography and mass spectrometry in food allergen detection. Journal of Food Protection, 74(2), 316e345.

Fedio, W. M., Jinneman, K. C., Yoshitomi, K. J., Zapata, R., Wendakoon, C. N., Browning, P., et al. (2011). Detection of E. coli O157:H7 in raw ground beef by Pathatrix (TM) immunomagneticseparation, real-time PCR and cultural methods. International Journal of Food Microbiology, 148(2), 87e92.

Frenzel, H., Lajn, A., \& Grundmann, M. (2013). One decade of fully transparent oxide thin-film transistors: fabrication, performance and stability. Physica Status Solidi e Rapid Research Letters, 7(9), $605 e 615$.

Gholami, S., \& Kompany-Zareh, M. (2013). Multiway study of hybridization in nanoscale semiconductor labeled DNA based on fluorescence resonance energy transfer. Physical Chemistry Chemical Physics, 15(34), 14405e14413. Godoy-Navajas, J., Caballos, M. P. A., \& Gomez-Hens, A. (2011). Heterogeneous immunoassay for soy protein determination using nile blue-doped silica nanoparticles as labels and front-surface longwavelength 
fluorimetry. Analytica Chimica Acta, 701(2), 194e199.

196 K. Warriner et al. / Trends in Food Science \& Technology 40 (2014) 183e199

Gomez, J. L., \& Tigli, O. (2013). Zinc oxide nanostructures: from

growth to application. Journal of Materials Science, 48(2),

$612 \mathrm{e} 624$.

Hu, Y. F., Zhang, Z. H., Zhang, H. B., Luo, L. J., \& Yao, S. Z. (2012).

Sensitive and selective imprinted electrochemical sensor for pnitrophenol

based on $\mathrm{ZnO}$ nanoparticles/carbon nanotubes doped

chitosan film. Thin Solid Films, 520, 5314e5321.

Jiang, X. R., Shao, N., Jing, W. W., Tao, S. C., Liu, S. X., \& Sui, G. D.

(2014). Microfluidic chip integrating high throughput continuous-

flow PCR and DNA hybridization for bacteria analysis. Talanta,

$122,246 \mathrm{e} 250$.

Ju, H., Zhang, X., Wang, J., Ju, H. X., Zhang, X. J., \& Wang, J. (2011).

Biosensing applications of molecularly imprinted nanomaterials.

NanoBiosensing: Principles, Development and Application,

$265 \mathrm{e} 303$.

Kanayeva, D. A., Wang, R. H., Rhoads, D., Erf, G. F., Slavik, M. F.,

Tung, S., et al. (2012). Efficient separation and sensitive detection

of Listeria monocytogenes using an impedance immunosensor

based on magnetic nanoparticles, a microfluidic chip, and an

interdigitated microelectrode. Journal of Food Protection, 75(11), $1951 \mathrm{e} 1959$.

Kim, Y. J., Hwang, K. H., Park, S. J., Jeon, D. Y., Nam, C. H., \& Kim, G. T. (2013). Fabrication of a silica nanocable using hydroxyl-group core-engineered filamentous virus. Journal of Nanoscience and Nanotechnology, 13(9), 6203e6207.

Kumar, S., Kumar, S., Ali, M. A., Anand, P., Agrawal, V. V., John, R., et al. (2013). Microfluidic-integrated biosensors: prospects for point-of-care diagnostics. Biotechnology Journal, 8(11), $1267 \mathrm{e} 1279$. 
Lakshmanan, R. S., Guntupalli, R., Hu, J., Kim, D.-J., Petrenko, V. A., Barbaree, J. M., et al. (2007). Phage immobilized magnetoelastic sensor for the detection of Salmonella typhimurium. Journal of Microbiological Methods, 71(1), 55e60.

Lee, J. W., Song, J., Hwang, M. P., \& Lee, K. H. (2013). Nanoscale bacteriophage biosensors beyond phage display. International Journal of Nanomedicine, 8, 3917e3925.

Li, C., \& Shi, G. Q. (2014). Carbon nanotube-based fluorescence sensors. Journal of Photochemistry and Photobiology CPhotochemistry Reviews, 19, 20e34.

Li, Q., Cheng, K., Weng, W., Du, P., \& Han, G. (2012). Highly sensitive hydrogen peroxide biosensors based on $\mathrm{TiO}_{2}$ nanodots/ITO electrodes. Journal of Materials Chemistry, 22, 9019 e9026.

Lim, B., \& Kim, Y. P. (2014). Enzymatic glucose biosensors based on nanomaterials. In M. B. Gu, \& H. S. Kim (Eds.). Biosensors based on aptamers and enzymes, (Vol. 140 pp. 203e219). Berlin: Springer-Verlag. Lima, F., \& Maia, G. (2014). Direct electron transfer from alcohol dehydrogenase (Article). RSC Advances, 4(43), 22575e22588. Lin, T. W., Liu, C. J., \& Dai, C. S. (2014). Ni3S2/carbon nanotube nanocomposite as electrode material for hydrogen evolution reaction in alkaline electrolyte and enzyme-free glucose detection. Applied Catalysis B e Environmental, 154, 213e220. Lindhardt, C., Schoenenbruecher, H., Slaghuis, J., Bubert, A., Ossmer, R., Junge, B., Harzman, C., \& Berghof-Jaeger, K. (2010). Salmonella Detection in Peanut Butter: Validation of a Real-Time Time PCR Method. Alimentaria, 85e88.

Liu, B. H., Cao, Y., Chen, D. D., Kong, J. L., \& Deng, J. Q. (2003). Amperometric biosensor based on a nanoporous $\mathrm{ZrO} 2$ matrix. Analytica Chimica Acta, 478, 59e66. 
Liu, Y., Zhang, L., Guo, Q. H., Hou, H. Q., \& You, T. Y. (2010).

Enzyme-free ethanol sensor based on electrospun nickel nanoparticle-loaded carbon fiber paste electrode. Analytica Chimica Acta, 663(2), 153e157.

Luo, X. L., Xu, J. J., Zhao, W., \& Chen, H. Y. (2004). A novel glucose ENFET based on the special reactivity of $\mathrm{MnO} 2$ nanoparticles.

Biosensors \& Bioelectronics, 19, 1295e1300.

Magana, S., Schlemmer, S. M., Leskinen, S. D., Kearns, E. A., \&

Lim, D. V. (2013). Automated dead-end ultrafiltration for

concentration and recovery of total coliform bacteria and laboratory-spiked Escherichia coli 0157:H7 from 50-liter produce washes to enhance detection by an electrochemiluminescence immunoassay. Journal of Food Protection, 76(7), 1152e1160.

Majdalawieh, A., Kanan, M. C., El-Kadri, O., \& Kanan, S. M. (2014). Recent advances in gold and silver nanoparticles: synthesis and applications. Journal of Nanoscience and Nanotechnology, 14(7), $4757 \mathrm{e} 4780$.

McCullum, C., Tchounwou, P., Ding, L. S., Liao, X., \& Liu, Y. M. (2014). Extraction of aflatoxins from liquid foodstuff samples with polydopamine-coated superparamagnetic nanoparticles for HPLCMS/MS analysis. Journal of Agricultural and Food Chemistry, 62(19), 4261e4267.

Meyer, R. (2000). Authenticity testing of food by PCR methods. New Food, 3(1), 24e27.

Mi-Kyung, P., Suiqiong, L., \& Chin, B. A. (2013). Detection of Salmonella Typhimurium grown directly on tomato surface using phage-based magnetoelastic biosensors. Food and Bioprocess Technology, 6(3), 682e689.

Mikulikova, R., Svoboda, Z., \& Belakova, M. (2008). Monitoring of residues of fungicides used in malting barley protection. Kvasny Prumysl, 54(11e12), 332e337. 
Mishra, S. K., Srivastava, A. K., Kumar, D., Biradar, A. M., \& Rajesh.

(2013). Microstructural and electrochemical impedance

characterization of bio-functionalized ultrafine ZnS nanocrystalsreduced graphene oxide hybrid for immunosensor applications.

Nanoscale, 5(21), 10494e10503.

Moghaddam, A. B., Ganjali, M. R., Saboury, A., MoosaviMovahedi, A. A., \& Norouzi, P. (2008). Electrodeposition of nickel oxide nanoparticles on glassy carbon surfaces: application to the direct electron transfer of tyrosinase. Journal of Applied Electrochemistry, 38, 1233e1239.

Mortari, A., \& Lorenzelli, L. (2014). Recent sensing technologies for pathogen detection in milk: a review. Biosensors \& Bioelectronics, $60,8 \mathrm{e} 21$.

Nagy, A., Gemmill, K. B., Delehanty, J. B., Medintz, I. L., \& Sapsford, K. E. (2014). Peptide-functionalized quantum dot biosensors. IEEE Journal of Selected Topics in Quantum Electronics, 20, 12.

Nahavandi, S., Baratchi, S., Soffe, R., Tang, S. Y., Mitchell, A., \& Khoshmanesh, K. (2014). Microfluidic platforms for biomarker analysis. Lab on a Chip, 14(9), 1496e1514.

Namvar, A., Haq, I., Shields, M., Amoako, K. K., \& Warriner, K. (2013). Extraction of Bacillus endospores from water, apple juice concentrate, raw milk and lettuce rinse solutions using tangential flow filtration. Food Control, 32(2), 632e637.

Neethirajan, S., Freund, M., \& Jayas, D. S. (2013). Poly(aniline boronic acid) polymers and methods of use.United States Patent, 8454819 B2. Ochoa, M. L., \& Harrington, P. B. (2005). Immunomagnetic isolation of enterohemorrhagic Escherichia coli O157 : H7 from ground beef and identification by matrix-assisted laser desorption/ ionization time-of-flight mass spectrometry and database searches. Analytical Chemistry, 77(16), 5258e5267.

Palanisamy, S., Cheemalapati, S., \& Chen, S.-M. (2012). An enzymatic 
biofuel cell based on electrochemically reduced graphene oxide and multiwalled carbon nanotubes/Zinc oxide modified electrode. International Journal of Electrochemical Science, 7, 11477e11487. Palecek, E., \& Bartosik, M. (2012). Electrochemistry of nucleic acids. Chemical Reviews, 112(6), 3427e3481.

Paniel, N., Baudart, J., Hayat, A., \& Barthelmebs, L. (2013). Aptasensor and genosensor methods for detection of microbes in real world samples. Methods, 64(3), 229e240.

Pereira, V. L., Fernandes, J. O., \& Cunha, S. C. (2014). Mycotoxins in cereals and related foodstuffs: a review on occurrence and recent methods of analysis. Trends in Food Science \& Technology, 36(2), $96 \mathrm{e} 136$.

K. Warriner et al. / Trends in Food Science \& Technology 40 (2014) 183e199 197

Pieta, P. P., Szczerba, A., Dobroczynska, J. I., \& Grabas, K. (2013).

Application of an aptamer and a regent based on gold nanoparticles for detection of Escherichia coli. Environment Protection Engineering, 39(4), 125e133.

Pilolli, R., Monaci, L., \& Visconti, A. (2013). Advances in biosensor development based on integrating nanotechnology and applied to food-allergen management. TrAC e Trends in Analytical Chemistry, 47, $12 \mathrm{e} 26$.

Pisanic li, T. R., Zhang, Y., \& Wang, T. H. (2014). Quantum dots in diagnostics and detection: principles and paradigms. The Analyst, 139(12), 2968e2981.

Rawal, R., Chawla, S., \& Pundir, C. S. (2012). An electrochemical sulfite biosensor based on gold coated magnetic nanoparticles modified gold electrode. Biosensors \& Bioelectronics, 31(1), 144e150.

Reddy, S. M., Hawkins, D. M., Phan, Q. T., Stevenson, D., \& Warriner, K. (2013). Protein detection using hydrogel-based molecularly imprinted polymers integrated with dual polarisation interferometry. Sensors and Actuators B e Chemical, 176, 190e197. 
Reddy, S. M., Phan, Q. T., El-Sharif, H., Govada, L., Stevenson, D., \& Chayen, N. E. (2012). Protein crystallization and biosensor applications of hydrogel-based molecularly imprinted polymers. Biomacromolecules, 13(12), 3959e3965.

Salian, V. D., \& Byrne, M. E. (2013). Living radical polymerization and molecular imprinting: improving polymer morphology in imprinted polymers. Macromolecular Materials and Engineering, 298(4), 379e390.

Scognamiglio, V. (2013). Nanotechnology in glucose monitoring: advances and challenges in the last 10 years. Biosensors \& Bioelectronics, 47, 12e25.

Shen, Z., Hou, N., Jin, M., Qiu, Z., Wang, J., Zhang, B., et al. (2014). A novel enzyme-linked immunosorbent assay for detection of Escherichia coli 0157:H7 using immunomagnetic and beacon gold nanoparticles. Gut Pathogens, 6, 14.

Shlyapnikov, Y. M., Shlyapnikova, E. A., Simonova, M. A., Shepelyakovskaya, A. O., Brovko, F. A., Komaleva, R. L., et al. (2012). Rapid simultaneous ultrasensitive immunodetection of five bacterial toxins. Analytical Chemistry, 84(13), 5596e5603.

Shu, B. W., Zhang, C. S., \& Xing, D. (2014). Segmented continuousflow multiplex polymerase chain reaction microfluidics for highthroughput and rapid foodborne pathogen detection. Analytica Chimica Acta, 826, 51e60.

Singh, R., Das Mukherjee, M., Sumana, G., Gupta, R. K., Sood, S., \& Malhotra, B. D. (2014). Biosensors for pathogen detection: a smart approach towards clinical diagnosis. Sensors and Actuators B e Chemical, 197, 385e404.

Singh, A., Poshtiban, S., \& Evoy, S. (2013). Recent advances in bacteriophage based biosensors for food-borne pathogen detection. Sensors, 13(2), 1763e1786. Sliwinska, M., Wisniewska, P., Dymerski, T., Namiesnik, J., \& 
Wardencki, W. (2014). Food analysis using artificial senses.

Journal of Agricultural and Food Chemistry, 62(7), 1423e1448.

Smartt, A. E., Xu, T. T., Jegier, P., Carswell, J. J., Blount, S. A.,

Sayler, G. S., et al. (2012). Pathogen detection using engineered

bacteriophages. Analytical and Bioanalytical Chemistry, 402(10),

$3127 \mathrm{e} 3146$.

Song, H. S., Kwon, O. S., Lee, S. H., Park, S. J., Kim, U.-K., Jang, J., et al. (2013). Human taste receptor-functionalized field effect transistor as a human-like nanobioelectronic tongue. Nano Letters, 13(1), $172 \mathrm{e} 178$.

Speranskaya, E. S., Beloglazova, N. V., Lenain, P., De Saeger, S., Wang, Z. H., Zhang, S. X., et al. (2014). Polymer-coated fluorescent CdSe-based quantum dots for application in immunoassay. Biosensors \& Bioelectronics, 53, 225e231. Speroni, F., Elviri, L., Careri, M., \& Mangia, A. (2010). Magnetic particles functionalized with PAMAM-dendrimers and antibodies: a new system for an ELISA method able to detect Ara h3/4 peanut allergen in foods. Analytical and Bioanalytical Chemistry, 397(7), 3035e3042. Sun, R. (2013). Fabrication of tobacco mosaic virus imprinted polymer on the surface of paramagnetic nanobeads via surfaceinitiated atom transfer radical polymerization (MSc thesis). University of Guelph. https://dspace.lib.uoguelph.ca/xmlui/ handle/10214/7695 Accessed 20.06.14.

Sung, Y. J., Suk, H. J., Sung, H. Y., Li, T., Poo, H., \& Kim, M. G. (2013). Novel antibody/gold nanoparticle/magnetic nanoparticle nanocomposites for immunomagnetic separation and rapid colorimetric detection of Staphylococcus aureus in milk (Article). Biosensors \& Bioelectronics, 43, 432e439.

Teymourian, H., Salimi, A., \& Hallaj, R. (2012). Low potential detection of $\mathrm{NADH}$ based on $\mathrm{Fe} 3 \mathrm{O} 4$ nanoparticles/multiwalled carbon nanotubes composite: fabrication of integrated 
dehydrogenase-based lactate biosensor. Biosensors \&

Bioelectronics, 33(1), 60e68.

Thakur, M. S., \& Ragavan, K. V. (2013). Biosensors in food processing. Journal of Food Science and Technology e Mysore, 50(4),

$625 \mathrm{e} 641$.

Tothill, I. E. (2011). Biosensors and nanomaterials and their application for mycotoxin determination (Article). World Mycotoxin Journal, 4(4), 361e374.

Varshney, M., Li, Y., Srinivasan, B., \& Tung, S. (2007). A label-free, microfluidics and interdigitated array microelectrode-based impedance biosensor in combination with nanoparticles immunoseparation for detection of Escherichia coli 0157: H7 in food samples. Sensors and Actuators B e Chemical, 128(1), $99 \mathrm{e} 107$.

Wang, H., Li, Y. B., Wang, A., \& Slavik, M. (2011). Rapid, sensitive, and simultaneous detection of three foodborne pathogens using magnetic nanobead-based immunoseparation and quantum dotbased multiplex immunoassay. Journal of Food Protection, 74(12), 2039 e2047.

Wang, H., Zhang, Y., Li, H., Du, B., Ma, H., Wu, D., et al. (2013). A silver-palladium alloy nanoparticle-based electrochemical biosensor for simultaneous detection of ractopamine, clenbuterol and salbutamol. Biosensors \& Bioelectronics, 49, 14e19.

Wang, Z., Fan, Y., Chen, J., Guo, Y., Wu, W., He, Y., et al. (2013). A microfluidic chip-based fluorescent biosensor for the sensitive and specific detection of label-free single-base mismatch via magnetic beads-based "sandwich" hybridization strategy. Electrophoresis, 34(15), $2177 \mathrm{e} 2184$.

Warner, M. G., Grate, J. W., Tyler, A., Ozanich, R. M., Miller, K. D., Lou, J., et al. (2009). Quantum dot immunoassays in renewable surface column and 96-well plate formats for the fluorescence 
detection of botulinum neurotoxin using high-affinity antibodies. Biosensors \& Bioelectronics, 25(1), 179e184.

Warriner, K., Morrissey, A., Alderman, J., King, G., Treloar, P., \& Vadgama, P. M. (2002). Modified microelectrode interfaces for inline electrochemical monitoring of ethanol in fermentation processes. Sensors and Actuators B e Chemical, 84(2e3), $200 \mathrm{e} 207$. Wu, W.-h., Li, M., Wang, Y., Ouyang, H.-x., Wang, L., Li, C.-X., et al. (2012). Aptasensors for rapid detection of Escherichia coli 0157:H7 and Salmonella typhimurium. Nanoscale Research Letters, 7. Yang, Z. J., Tang, Y., Li, J., Zhang, Y. C., \& Hu, X. Y. (2014). Facile synthesis of tetragonal columnar-shaped $\mathrm{TiO}_{2}$ nanorods for the construction of sensitive electrochemical glucose biosensor. Biosensors \& Bioelectronics, 54, 528e533.

Zhang, C. Y., Yeh, H. C., Kuroki, M. T., \& Wang, T. H. (2005). Singlequantum-dot-based DNA nanosensor. Nature Materials, 4(11),

$826 \mathrm{e} 831$.

Zhang, H. J., Li, W. Q., Gu, Y. J., \& Zhang, S. W. (2014). Preparation and catalytic activity of poly(N-vinyl-2-pyrrolidone)-protected $\mathrm{Au}$ nanoparticles for the aerobic oxidation of glucose. Journal of Nanoscience and Nanotechnology, 14(8), 5743e5751.

Zhao, X. J., Hilliard, L. R., Mechery, S. J., Wang, Y. P., Bagwe, R. P., Jin, S. G., et al. (2004). A rapid bioassay for single bacterial cell quantitation using bioconjugated nanoparticles. Proceedings of 198 K. Warriner et al. / Trends in Food Science \& Technology 40 (2014) 183e199 the National Academy of Sciences of the United States of America, 101(42), 15027e15032.

Zhao, Y. G., Yan, X. Q., Kang, Z., Lin, P., Fang, X. F., Lei, Y., et al. (2013).

Highly sensitive uric acid biosensor based on individual zinc oxide micro/nanowires. Microchimica Acta, 180(9e10), 759e766. Zhi, X., Deng, M., Yang, H., Gao, G., Wang, K., Fu, H. L., et al. (2014). A novel HBV genotypes detecting system combined with 
microfluidic chip, loop-mediated isothermal amplification and GMR sensors (Article). Biosensors \& Bioelectronics, 54, $372 \mathrm{e} 377$.

Zhou, L. T., Li, R. Y., Li, Z. J., Xia, Q. F., Fang, Y. J., \& Liu, J. K. (2012). An immunosensor for ultrasensitive detection of aflatoxin B-1 with an enhanced electrochemical performance based on graphene/ conducting polymer/gold nanoparticles/the ionic liquid composite film on modified gold electrode with electrodeposition. Sensors and Actuators B e Chemical, 174, 359e365. 
